\title{
Mechanism of NO-SCR by methane over Co,H-ZSM-5 and Co,H-mordenite catalysts
}

Ferenc Lónyi *, Hanna E. Solt, Zoltán Pászti, József Valyon

Institute of Materials and Environmental Chemistry, Research Center for Natural Sciences, Hungarian Academy of Sciences, Pusztaszeri u. 59-67, 1025 Budapest, Hungary

\begin{abstract}
Results of X-ray photoelectron spectroscopic (XPS) examination and temperatureprogrammed reduction measurements by $\mathrm{H}_{2}\left(\mathrm{H}_{2}-\mathrm{TPR}\right)$ showed that the Co-zeolite catalysts, which were found most active in the selective catalytic reduction of $\mathrm{NO}$ by methane to $\mathrm{N}_{2}$ in the presence of excess $\mathrm{O}_{2}$ (NO-SCR), contain both $\mathrm{Co}^{2+} /[\mathrm{Co}-\mathrm{OH}]^{+} / \mathrm{H}^{+}$exchange cations, Cooxo species and cobalt oxide clusters. Using operando Diffuse Reflectance Infrared Fourier Transform Spectroscopic method (DRIFTS method) the NO-SCR reaction was shown to proceed in consecutive steps via bifunctional mechanism over active sites (i) promoting the oxidation of $\mathrm{NO}$ by $\mathrm{O}_{2}$ to $\mathrm{NO}_{2}$ (NO-COX reaction), and sites (ii) whereon disproportionation and charge separation of $2 \mathrm{NO}_{2}$ generates activated surface intermediate $\mathrm{NO}_{3}{ }^{-} \mathrm{NO}^{+}$ion pair. Latter process was found to require $\mathrm{Co}^{2+}$ zeolite cations. The NO-COX reaction was shown to proceed over Co-oxo species and cobalt oxide, if present, and also over Brønsted acid sites but at a significantly lower rate. In the reaction of methane and the $\mathrm{NO}_{3}{ }^{-} / \mathrm{NO}^{+}$ion pair $\mathrm{CO}_{2}$, $\mathrm{H}_{2} \mathrm{O}$, and $\mathrm{N}_{2}$ was formed and the active $\mathrm{Co}^{2+}$ sites were recovered $\left(\mathrm{CH}_{4} / \mathrm{NO}-\mathrm{SCR}\right.$ reaction). The surface concentration of the $\mathrm{NO}_{3}{ }^{-} / \mathrm{NO}^{+}$ion pair must have been controlled by the relative magnitude of the apparent rate constants of the consecutive $\mathrm{NO}-\mathrm{COX}$ and $\mathrm{CH}_{4} / \mathrm{NO}-\mathrm{SCR}$ reactions. Below about $700 \mathrm{~K}$ reaction temperature latter reaction governed the rate of the consecutive NO reduction process. Above about $700 \mathrm{~K}$ combustion became the main reaction of methane. Because of the low equilibrium $\mathrm{NO}_{2}$ concentration at these high temperatures the NO-COX reaction took over the control over the rate of the NO-SCR process. Under steady state reaction conditions a temperature-dependent fraction of the $\mathrm{Co}^{2+}$ active sites was always poisoned by adsorbed $\mathrm{H}_{2} \mathrm{O}$ formed in the $\mathrm{CH}_{4}$ oxidation reaction.
\end{abstract}

Keywords: Co,H-zeolites; NO-SCR by $\mathrm{CH}_{4}$; Operando-DRIFTS; reaction mechanism

\footnotetext{
* Corresponding author. Tel.: +36 1438 1162; fax: +36 14381164.

E-mail address: lonyi.ferenc@ttk.mta.hu (F. Lónyi).
} 


\section{Introduction}

The selective catalytic reduction $(\mathrm{SCR})$ of $\mathrm{NO}_{\mathrm{x}}$ by methane is an attractive technology for $\mathrm{NO}_{\mathrm{x}}$ abatement of oxygen-rich emissions of stationary sources, such as boilers and engines fuelled by natural gas [1-4].

The reduction of NO by methane in the presence of $\mathrm{O}_{2}$ requires catalytic activation of the reactants. First Li and Armor [1,2] recognized that cobalt, supported on zeolites showed relatively high catalytic activity in the reaction. Later on a few other supported metal, such as, Pt, Pd, Ni, Mn, Ga, In, and their combinations were found to have also substantial activity [3]. Depending on the zeolite structure, catalyst composition and method of preparation the Cozeolite catalysts presented diverse activities. A number of studies were devoted to learn the underlying structural and compositional factors determining the NO-SCR activity of Cozeolites, however, the picture remained obscure. Studying Co,In-zeolites we demonstrated recently that efficient NO-SCR reaction by methane requires two independent catalytic functions. One of these must promote $\mathrm{NO}_{2}$-forming reaction (NO-COX reaction) and the other has to generate active surface $\mathrm{NO}_{\mathrm{x}}$ intermediates that are believed to have significance in the $\mathrm{N}_{2}$ forming reaction with methane $\left(\mathrm{CH}_{4} / \mathrm{NO}-\mathrm{SCR}\right.$ reaction) [5]. The knowledge gathered before about the mechanism of selective NO reduction over Co,In-zeolite catalysts was found beneficial in attaining a better understanding of the overall mechanism of the reaction over Co-zeolites. The lesson learned is reported in the present paper.

The state of art about the NO-SCR over Co-zeolites can be briefly summarized as follows. In the presence of oxygen the $\mathrm{NO}$ was found to form Co-bound adsorbed $\mathrm{NO}_{\mathrm{x}}$ species $(x=2,3)$ that was suggested to be essential to oxidize $\mathrm{CH}_{4}$ and to get somehow $\mathrm{N}_{2}$ [612]. However, the way of formation and the nature of the active surface-bound $\mathrm{NO}_{\mathrm{x}}$, as well as, the way of the N-N bond formation remained a matter of discussion.

It was suggested that the $\mathrm{NO}_{\mathrm{x}}$ species was obtained simply via $\mathrm{O}_{2}$ oxidation of $\mathrm{NO}$, bound to $\mathrm{Co}^{2+}[6,7,11]$, or by the reaction of $\mathrm{NO}$ with superoxide ion $\mathrm{O}_{2}{ }^{-}$formed in the interaction of $\mathrm{Co}^{2+}$ sites and $\mathrm{O}_{2}$ [4,13]. It was shown long ago that the high electric field inside the zeolite cavities can induce charge separation of $\mathrm{NO}_{2}$ to $\mathrm{NO}_{2}{ }^{+} / \mathrm{NO}_{2}{ }^{-}$ion pair [14]. Using infrared spectroscopy the $\mathrm{NO}_{x}$ was identified as $\mathrm{NO}_{3}{ }^{-}$and $\mathrm{NO}^{+}$species obtained from the adsorption of $\mathrm{NO} / \mathrm{O}_{2}$ mixture [4,15-17]. In recent publications we confirmed the simultaneous formation of these species over $[\mathrm{InO}]^{+}$or $\mathrm{Co}^{2+}$ forms of zeolites $[5,17,18]$. The positive charge on the cobalt and the negative charge on the zeolite framework pose an electrostatic field in the zeolite cavity that can give rise not only to charge separation but also 
to disproportionation of $2 \mathrm{NO}_{2}$ to obtain $\mathrm{NO}_{3}{ }^{-} / \mathrm{NO}^{+}$ion pair. The appearance of mentioned species assumes the preceding formation of $\mathrm{NO}_{2}$ that sometimes appear also in the product mixture of the NO-SCR reaction. At high NO concentration the equilibration of the $\mathrm{NO} / \mathrm{NO}_{2} / \mathrm{O}_{2}$ system is quite facile even around room temperature. However, at low concentrations $(\leq 4000 \mathrm{ppm})$ and temperature $(<\sim 700 \mathrm{~K})$ the equilibration reaction is kinetically hindered. It is believed that catalytic promotion of the reaction is needed to approach equilibrium more rapidly and, thereby, to accelerate $\mathrm{NO}_{\mathrm{x}}$ formation, methane activation and the NO-SCR reaction [19]. However, Busca et al. $[10,11]$ questioned that $\mathrm{NO}_{2}$ could play any role in the NO-SCR mechanism. Instead, $\mathrm{NO}_{2}$ was considered as undesired byproduct, which competed with the reaction producing $\mathrm{N}_{2}$ especially at lower temperatures $(<700 \mathrm{~K})$ where the $\mathrm{NO}_{2}$ formation was thermodynamically favored.

Regarding the intermediates of the $\mathrm{N}_{2}$-forming reaction of $\mathrm{NO}$ and methane in the presence of $\mathrm{O}_{2}$ the opinions are rather speculative and often contradictory. According to above reasoning $\mathrm{NO}_{2}$ is one of the possible intermediates of the NO-SCR reaction [9,20-22]. In order to describe the process of $\mathrm{N}-\mathrm{N}$ coupling in the reaction of surface $\mathrm{NO}_{\mathrm{x}}$ and methane nitro- or nitrosomethane was visualized as a transient species that pass through a series of poorly defined transformations before a derivative thereof, containing nitrogen in a reduced electronic state, like $\mathrm{NH}_{\mathrm{x}}$, nitrile, or isocyanate, reacts with a species, containing nitrogen in oxidized electronic state, like $\mathrm{NO}$ or $\mathrm{NO}_{2}$, to give $\mathrm{N}_{2}$ [6-10]. We have found, using In-zeolite catalysts, that not the gas phase reactant but the surface-bound $\mathrm{NO}^{+}$, formed together with $\mathrm{NO}_{3}{ }^{-}$ion, is a likely reaction partner in this last $\mathrm{N}_{2}$ forming reaction step [5,18].

The Co-species in the Co-form zeolites are quite well described [3,11,22-30]. Depending on the preparation method Co-zeolites can contain different active Co centers in variable proportions, such as, (i) $\mathrm{Co}^{2+}$ cations in ion-exchange positions of the zeolite, (ii) $\mathrm{Co}-$ oxocations or oxide-like Co species inside the pores of zeolites, and (iii) Co-oxide clusters on the outer surface of the zeolite crystallites. However, the participation and the particular role of these Co-species in the NO-SCR reaction are not fully clarified yet. It is generally accepted that the Co-oxide or oxide like Co species can enhance $\mathrm{NO}_{2}$ formation $[3,22,25,26,31]$ and also initiate methane combustion [24,26,29,32,33]. However, contradictory opinions were expressed about the role of $\mathrm{Co}^{2+}$ cations. Although these cations are usually the most abundant Co-species in the Co-zeolites the real active sites of NO-SCR by methane was claimed to be cobalt oxide microaggregates or clusters in the zeolite pores [29,30].

In the present study, we show that the NO-SCR by methane proceeds on a similar mechanistic route over Co-zeolite catalysts than that described before for Co,In-zeolite 
catalysts. It is also shown that the various cobalt species, generated during the catalyst preparations, present different kinds of catalytic activities and their proportions determine the NO-SCR activity of the Co-zeolite catalyst.

\section{Experimental}

\subsection{Catalyst preparation}

Two methods were applied for the introduction of cobalt in zeolite samples, namely liquid phase ion exchange (IE) and solid state reaction (SSR). The IE was carried out by stirring $10 \mathrm{~g}$ of $\mathrm{H}-\mathrm{ZSM}-5$ (our synthetic product; $\mathrm{Si} / \mathrm{Al}_{\mathrm{T}}=29.7$ and $\mathrm{Si} / \mathrm{Al}_{\mathrm{F}}=33.0$, where $\mathrm{Al}_{\mathrm{T}}$ and $\mathrm{Al}_{\mathrm{F}}$ represent the total and the framework aluminum content, respectively) or $\mathrm{H}$ mordenite $\left(\mathrm{H}-\mathrm{M}\right.$, Süd-Chemie $\left.\mathrm{AG} ; \mathrm{Si} / \mathrm{Al}_{\mathrm{F}}=6.7\right)$ sample in $500 \mathrm{ml}$ of a $0.1 \mathrm{M} \mathrm{Co}\left(\mathrm{NO}_{3}\right)_{2}$ solution at $343 \mathrm{~K}$ under reflux for 6 hours. Then the slurry was filtered, washed with distilled water and dried in an oven at $383 \mathrm{~K}$. The ion-exchanged samples were designated as $\mathrm{Co}^{\mathrm{IE}}, \mathrm{H}-$ ZSM-5 and $\mathrm{Co}^{\mathrm{IE}}, \mathrm{H}-\mathrm{M}$, respectively. The SSR method involved the thermally induced reaction of the H-ZSM-5 or H-M sample with a calculated amount of $\mathrm{Co}\left(\mathrm{CH}_{3} \mathrm{COO}\right)_{2} \cdot 4 \mathrm{H}_{2} \mathrm{O}$ in the solid state. A similar procedure was applied than that described in refs. [23] and [24]. The zeolite and cobalt acetate powders were mixed by intense co-grinding. The mixture was heated up to $823 \mathrm{~K}$ at a heating rate of $10 \mathrm{~K} / \mathrm{min}$ to $823 \mathrm{~K}$ in a He flow $\left(30 \mathrm{~cm}^{3} \cdot \mathrm{min}^{-1}\right)$ and kept at this temperature for 2 hours. The samples prepared by the above outlined method were designated as $\mathrm{Co}^{\mathrm{SSR}}, \mathrm{H}-\mathrm{ZSM}-5$ and $\mathrm{Co}^{\mathrm{SSR}}, \mathrm{H}-\mathrm{M}$, respectively.

Additional catalyst samples, designated as $\mathrm{Co}^{\mathrm{SSR}}, \mathrm{Co}^{\mathrm{IE}}, \mathrm{H}-\mathrm{ZSM}-5$ and $\mathrm{Co}^{\mathrm{SSR}}, \mathrm{Co}^{\mathrm{IE}}, \mathrm{H}-\mathrm{M}$, were prepared using aliquot parts of the IE samples and applying the above described SSR method. The catalyst preparations and their composition, determined by rendering the sample soluble and using atomic absorption spectroscopic analysis, are listed in Table 1.

\subsection{Temperature-programmed reduction by hydrogen $\left(H_{2}-T P R\right)$}

The $\mathrm{H}_{2}$-TPR measurements were carried out using a flow-through microreactor (I.D. $4 \mathrm{~mm}$ ) made of quartz. About $150 \mathrm{mg}$ of catalyst sample (particle size: $0.25-0.5 \mathrm{~mm}$ ) was placed into the microreactor and was pretreated in a $30 \mathrm{~cm}^{3} \cdot \mathrm{min}^{-1}$ flow of $\mathrm{O}_{2}$ at $773 \mathrm{~K}$ for 1 hour. The pre-treated sample was purged then with $\mathrm{N}_{2}$ at $773 \mathrm{~K}$ and cooled to room temperature in the same $\mathrm{N}_{2}$ flow before contacting with a $30 \mathrm{~cm}^{3} \cdot \mathrm{min}^{-1}$ flow of $10 \% \mathrm{H}_{2} / \mathrm{N}_{2}$ 
mixture. The reactor temperature was ramped up at a rate of $10 \mathrm{~K} \cdot \mathrm{min}^{-1}$ to $1073 \mathrm{~K}$, while the effluent gas was passed through a dry-ice trap and a thermal conductivity detector (TCD). Data were collected and processed by computer. Hydrogen consumption was calculated from the area of the TPR peak using a calibration value determined by $\mathrm{H}_{2}$-TPR of $\mathrm{CuO}$ reference material.

\subsection{X-ray photoelectron spectroscopy}

XPS analyses were carried out using a multi-technique system manufactured by Omicron Nanotechnology GmbH. The system was equipped with a dual $\mathrm{Mg} / \mathrm{Al} \mathrm{X}$-ray source and a hemispherical EA 125 analyzer operating in fixed analyzer transmission (FAT) mode. Each catalyst sample was pretreated ex situ in a $30 \mathrm{~cm}^{3} \cdot \mathrm{min}^{-1}$ flow of $\mathrm{O}_{2}$ at $773 \mathrm{~K}$ for 1 hour before the XPS experiments. Before collecting spectra, the pellet, pressed from the pretreated catalyst powder, was annealed in situ in vacuum at $673 \mathrm{~K}$ for 1 hour then cooled to room temperature. The spectra were obtained with pass energy of $30 \mathrm{eV}$; the $\mathrm{Al}-\mathrm{K} \alpha \mathrm{X}$-ray source was operated at $150 \mathrm{~W}$ and $15 \mathrm{kV}$. The working pressure in the analyzing chamber was less than $1 \times 10^{-9}$ mbar. The spectral regions corresponding to Co 2 p, O 1s, C 1s, Si 2p, Si 2 s and Al $2 p$ core levels were recorded for each sample. The BE reference value was $\mathrm{Si}_{2 p}=102.9$ eV [34]. The data treatment was performed with the Casa XPS program (Casa Software Ltd, UK). The peak areas were determined by integration employing a Shirley-type background. Peaks were considered to be a mixture of Gaussian and Lorentzian functions in 70 to 30 ratio. For the quantification of the elements, integrated intensities were processed by the software XPSMultiQuant [35] by assuming homogeneous depth distribution for the sample constituents.

\subsection{Catalytic activity}

About $100 \mathrm{mg}$ of catalyst (particle size: $0.25-0.5 \mathrm{~mm}$ ) was placed into the same flow-through microreactor as used for the $\mathrm{H}_{2}$-TPR measurements. The catalyst was pretreated in a $30 \mathrm{~cm}^{3} \cdot \mathrm{min}^{-1}$ flow of $10 \% \mathrm{O}_{2} / \mathrm{He}$ at $823 \mathrm{~K}$ for $1 \mathrm{~h}$, then was purged with pure $\mathrm{He}$ and cooled to $573 \mathrm{~K}$. The catalytic activities in the selective catalytic reduction (NO-SCR) and in the catalytic oxidation of $\mathrm{NO}$ to $\mathrm{NO}_{2}$ with $\mathrm{O}_{2}$ (NO-COX) were determined at temperatures between 573 and $823 \mathrm{~K}$. The reaction was initiated by switching the He flow to a flow of $4000 \mathrm{ppm} \mathrm{NO/4000} \mathrm{ppm} \mathrm{CH}_{4} / 2 \% \mathrm{O}_{2} / \mathrm{He}$ mixture (NO-SCR) or $4000 \mathrm{ppm} \mathrm{NO} / 2 \%$ 
$\mathrm{O}_{2} / \mathrm{He}$ mixture (NO-COX). From here on these gas mixtures are referred to as $\mathrm{NO} / \mathrm{CH}_{4} / \mathrm{O}_{2}$ or $\mathrm{NO} / \mathrm{O}_{2}$ mixtures without giving the concentrations and indicating the presence of helium. The total flow rate of the reaction mixture was usually $100 \mathrm{~cm}^{3} \cdot \mathrm{min}^{-1}$ throughout the catalytic experiments corresponding to about a GHSV value of $30000 \mathrm{~h}^{-1}$. (The bed volume was calculated using catalyst bulk density of $0.5 \mathrm{~g} \cdot \mathrm{cm}^{-3}$ ). In order to study the effect of space time on the catalytic conversion and product selectivity the GHSV was changed between 60000 and $6000 \mathrm{~h}^{-1}$. The reactor effluent was analyzed with an on-line mass spectrometer (MS, VG ProLab, Fisher Scientific) having a computer program for a quantitative analysis. The instrument was calibrated using gas mixtures with known compositions. The composition of the reactor effluent was continuously monitored.

The total conversions of NO and methane were calculated from the concentration of the reactant in the feed and in the reactor effluent. The MS determination of the $\mathrm{N}_{2}$ concentration from the intensity of the $\mathrm{m} / \mathrm{z}=28$ signal is uncertain because of the possible simultaneous presence of $\mathrm{CO}(\mathrm{m} / \mathrm{z}=28)$ in the gas. Therefore, the conversion to $\mathrm{N}_{2}$ was determined as the difference of the total $\mathrm{NO}$ conversion and the sum of the conversion to $\mathrm{NO}_{2}$ and twice the conversion to $\mathrm{N}_{2} \mathrm{O}$. Usually not any or only a trace amount of $\mathrm{N}_{2} \mathrm{O}$ could be detected. The concentrations obtained from the intensity of $\mathrm{m} / \mathrm{z}=28 \mathrm{MS}$ signal and that calculated for the $\mathrm{N}_{2}$ product as explained never deviated more than $\pm 5 \%$. This is suggesting that $\mathrm{CO}$ formation, if any, was insignificantly low.

\subsection{Operando DRIFTS investigations}

The surface species obtained from the adsorption of the reactants, their mixtures, and from the adsorption of their reaction products were studied by DRIFT spectroscopy using a Nicolet 5PC spectrometer, equipped with a COLLECTOR ${ }^{\mathrm{TM}}$ II diffuse reflectance mirror system and a flow-through DRIFT spectroscopic reactor cell (Spectra-Tech, Inc.). The same experimental conditions (temperature, reactant concentrations, and GHSV) applied for the DRIFT reactor cell as for the flow-through microreactor. The sample cup of the cell (I.D.: 5 $\mathrm{mm}$, height: $4 \mathrm{~mm}$ ) was filled with about $20 \mathrm{mg}$ of powdered sample. The DRIFT spectrum of the catalyst powder was taken at every selected reaction temperatures in He-flow. This spectrum was subtracted from the corresponding DRIFT spectrum of the catalyst in contact with the reactant in the cell to get a characteristic difference spectrum, showing the spectrum of the generated surface species, the gas phase (positive bands) and the spectrum of the lost 
species (negative bands). The concentration of the reactants and products leaving the cell were continuously monitored by on-line MS. Formation and/or loss of surface species was typically monitored either as function of reaction temperature or during transient experiments, wherein the concentration of $\mathrm{CH}_{4}$ was suddenly changed. The experimental set-up allowed abrupt switching between reactant mixtures $\mathrm{NO} / \mathrm{O}_{2}$ and $\mathrm{CH}_{4} / \mathrm{NO} / \mathrm{O}_{2}$. The partial pressures of $\mathrm{NO}$ and $\mathrm{O}_{2}$ were the same in the two gas mixtures. In latter mixture the $\mathrm{CH}_{4}$ was present on the expense of He balance gas. After a switch from He flow to the flow of the reactant mixture, the system reached a new steady state in about 4 to $8 \mathrm{~min}$, as it was shown by the stabilized MS peak intensities.

\section{Results}

\subsection{Catalyst characterization}

\subsection{1. $H_{2}-T P R$}

The $\mathrm{H}_{2}$-TPR curves obtained for the different Co-zeolites are shown in Fig. 1. A characteristic peak was obtained in the $623-673 \mathrm{~K}$ temperature range for all the samples, except for the $\mathrm{Co}^{\mathrm{IE}}, \mathrm{H}$-zeolites. Earlier studies assigned similar $\mathrm{H}_{2}$-TPR peaks to the reduction of cobalt oxides on the outer surface of zeolite crystallites [10,11,25,27,28]. The theoretical H/Co atomic ratio that corresponds to the full reduction of cobalt oxides ranges from $2.0(\mathrm{CoO})$ to $2.66\left(\mathrm{Co}_{3} \mathrm{O}_{4}\right)$. Values of $\mathrm{H} / \mathrm{Co}$ were obtained in this range but near to the upper limit suggesting that samples contain both kinds of oxides but mainly $\mathrm{Co}_{3} \mathrm{O}_{4}$ (Table 2). The very low hydrogen consumptions of $\mathrm{Co}^{\mathrm{IE}}, \mathrm{H}$-zeolites suggest that most cobalt are present in these preparations as hard-to-reduce $\mathrm{Co}^{2+}$ ion, balancing framework negative charge (Fig. 1 and Table 2). The $\mathrm{Co}^{2+}$ cations of zeolites were shown to become reduced only over about $1073 \mathrm{~K}$ $[10,11,25,27,28]$. The low intensity peaks in between 723 and $823 \mathrm{~K}$ indicate that some Cooxo species were also formed during preparation of the ion-exchanged Co-zeolite samples, which were most probably located within the zeolite pores [28]. Assuming that consumption of $1 \mathrm{~mol} \mathrm{H}_{2}$ corresponds to the reduction of $1 \mathrm{~mol}$ cobalt the estimated reducible fraction of the total cobalt content is about 4 and $16 \%$ for the $\mathrm{Co}^{\mathrm{IE}}, \mathrm{H}-\mathrm{ZSM}-5$ and $\mathrm{Co}^{\mathrm{IE}}, \mathrm{H}-\mathrm{M}$ samples, respectively. Samples containing cobalt introduced by both IE and SSR methods $\left(\mathrm{Co}^{\mathrm{SSR}}, \mathrm{Co}^{\mathrm{IE}}, \mathrm{H}\right.$-zeolites) present a dominating $\mathrm{H}_{2}$-TPR peak, which is similar to that characteristic for cobalt oxides on the outer surface of zeolite crystallites. Since the $\mathrm{Co}^{2+}$ species, also present in these samples, were not reduced in the applied temperature range, the 
$\mathrm{H} / \mathrm{Co}$ molar ratio is smaller than that obtained for the $\mathrm{Co}^{\mathrm{SSR}}, \mathrm{H}$-zeolites (Table 2). The cobalt oxide species of the $\mathrm{Co}^{\mathrm{SSR}}, \mathrm{Co}^{\mathrm{IE}}, \mathrm{H}$-zeolites were characterized by assigning the total $\mathrm{H}_{2}$ consumption to cobalt introduced by the SSR method (Table 2). This value hardly deviated from that obtained for the corresponding $\mathrm{Co}^{\mathrm{SSR}}, \mathrm{H}$-zeolite sample, indicating that the SSR method generates similar cobalt oxide species in the $\mathrm{H}$ - and $\mathrm{Co}^{\mathrm{IE}}, \mathrm{H}$-zeolites. The $\mathrm{H}_{2}$ consumptions are somewhat above the theoretical $\mathrm{H} / \mathrm{Co}=2.66$ value of $\mathrm{Co}_{3} \mathrm{O}_{4}$. The excess can come from the minor $\mathrm{H}_{2}$ consumption of the cobalt oxide introduced incidentally during the ion exchange procedure.

\subsubsection{XPS results}

The XPS spectra of the Co $2 p$ region are shown in Fig. 2. The component peak observed in the spectrum of the $\mathrm{Co}^{\mathrm{IE}}, \mathrm{H}-\mathrm{M}$ catalyst at the binding energy (BE) of $783.2 \mathrm{eV}$ (accompanied by a "shake up" line at $788.9 \mathrm{eV}$ ) can be assigned to the Co $2 \mathrm{p} 3 / 2$ level of $\mathrm{Co}^{2+}$ ions in ion-exchange positions [5,36]. An additional component band appears at BE of 779.6-780 eV in the spectra measured on $\mathrm{Co}^{\mathrm{SSR}}, \mathrm{Co}^{\mathrm{IE}}, \mathrm{H}-\mathrm{M}(1)$ and $\mathrm{Co}^{\mathrm{SSR}}, \mathrm{Co}^{\mathrm{IE}}, \mathrm{H}-\mathrm{ZSM}-5$, which can be attributed to Co-oxide (most probably $\mathrm{Co}_{3} \mathrm{O}_{4}$ and/or $\mathrm{CoO}$ ) [5,36]. The $\mathrm{H}_{2}-\mathrm{TPR}$ results suggest that cobalt introduced by IE and SSR method predominantly appears as $\mathrm{Co}^{2+}$ ions and Co-oxide, respectively. Therefore, the relative concentrations of these species should be about 3 to 1 in the $\mathrm{Co}^{\mathrm{SSR}}{ }_{,} \mathrm{Co}^{\mathrm{IE}}, \mathrm{H}-\mathrm{M}(1)$ and 1 to 1 in the and $\mathrm{Co}^{\mathrm{SSR}}{ }_{,} \mathrm{Co}^{\mathrm{IE}}{ }_{,} \mathrm{H}-\mathrm{ZSM}-5$ sample (Table 1). However, the intensity ratio of the peak assigned to $\mathrm{Co}^{2+}$ ions in ion-exchange position and the peak assigned to Co-oxide species does not reflect these concentration ratios. This discrepancy can be attributed to the fact that $\mathrm{Co}^{2+}$ ions in ion-exchange positions are homogenously distributed within the zeolite crystallites, whereas Co-oxide is present in form of particles heterogeneously distributed on the outer surface of the crystallites, the bulk of which is not accessible for XPS analysis. The contribution of $\mathrm{CoO}$ and $\mathrm{Co}_{3} \mathrm{O}_{4}$ to the peak of Co-oxide species can be theoretically determined via their distinct shake-up satellite structure [36]. The relatively low intensity of the band due to Co-oxide, however, does not allow us to distinguish these two oxide forms. Based on the hydrogen consumptions determined by $\mathrm{H}_{2}$ TPR Co-oxide is present predominantly in form of $\mathrm{Co}_{3} \mathrm{O}_{4}$ in the samples (Table 2).

\subsection{Catalytic results}

In Figs. 3 and 4 NO-SCR activities of Co,H-zeolite catalysts are shown as the function of reaction temperature. The catalysts containing $\mathrm{Co}^{2+}$ ions in the zeolite lattice have low 
activity but high selectivity in the conversion of $\mathrm{NO}$ to $\mathrm{N}_{2}$ (Figs. 3A and $4 \mathrm{~A}$ ). In the product gas minor amount of $\mathrm{NO}_{2}$ was detected at reaction temperatures below about $700 \mathrm{~K}$ (Fig. 4A). The methane conversion hardly exceeded the level defined by the stoichiometry of Eq. (1) (conversion ratio $\mathrm{CH}_{4} / \mathrm{NO}=0.5$ ).

$\mathrm{CH}_{4}+\mathrm{O}_{2}+2 \mathrm{NO} \rightarrow \mathrm{CO}_{2}+2 \mathrm{H}_{2} \mathrm{O}+\mathrm{N}_{2}$

In agreement with earlier results $[11,37,38]$ the $\mathrm{H}$-form zeolite catalysts, containing mainly extra-lattice oxide-like cobalt species, were very active in the oxidation of $\mathrm{NO}$ to $\mathrm{NO}_{2}$ (NO-COX). Low conversions to nitrogen were obtained only at reaction temperature above about $700 \mathrm{~K}$, where the combustion of methane became the main reaction. At these high temperatures the $\mathrm{NO}_{2}$ concentration of the reactor effluent approached the low value determined by the thermodynamic equilibrium of the NO oxidation reaction (Figs. 3B and $4 \mathrm{~B})$. When both $\mathrm{Co}^{2+}$ ions and Co-oxide species were present in the catalyst both $\mathrm{N}_{2}$ and $\mathrm{NO}_{2}$ were formed (Figs. 3C, 4C, and 4D). Note, however, that significantly less $\mathrm{NO}_{2}$ appeared in the product mixture in the presence than in the absence of $\mathrm{Co}^{2+}$ zeolite cations. Over about $700 \mathrm{~K}$ the NO-SCR reaction became selective in the sense that all the converted NO was converted to $\mathrm{N}_{2}$. The NO conversion was also higher over these zeolite catalysts than over those containing cobalt either as zeolite cation or as oxide-like cobalt species only. The increased conversion rate and the improved $\mathrm{N}_{2}$ selectivity suggest interplay between the Cooxide sites, catalyzing the $\mathrm{NO}_{2}$-generating $\mathrm{NO}-\mathrm{COX}$ reaction and $\mathrm{Co}^{2+}$ zeolite sites, responsible for the $\mathrm{N}_{2}$-forming $\mathrm{CH}_{4} / \mathrm{NO}$-SCR reaction. In agreement with earlier observations $[24,27,29,33]$ the former active sites seem to catalyze not only the NO-COX reaction but also the methane combustion reaction as shown by the methane conversion, which is, especially above $700 \mathrm{~K}$, excessive to that given by the stoichiometry of Eq. (1) (conversion ratio $\mathrm{CH}_{4} / \mathrm{NO}>0.5$ ) (Figs. 3B,C and 4B-D). In this respect, the proper balance of these two kinds of sites has significance. The catalyst $\mathrm{Co}^{\mathrm{SSR}}, \mathrm{Co}^{\mathrm{IE}}, \mathrm{H}-\mathrm{M}(2)$, containing twice as much Co-oxide beside the same amount $\mathrm{Co}^{2+}$ ions than catalyst $\mathrm{Co}^{\mathrm{SSR}}{ }^{\mathrm{C}} \mathrm{Co}^{\mathrm{IE}}, \mathrm{H}-\mathrm{M}(1)$ (Table 1), showed increased NO conversion and $\mathrm{N}_{2}$ selectivity below about $700 \mathrm{~K}$ reaction temperature (cf. Figs. 4C and D). However, above about $700 \mathrm{~K}$ the oxygen became the preferred reaction partner of methane. Thus, as far as the conversion of methane is concerned, the selectivity of the NOSCR reaction dropped at higher reaction temperatures, whereas the conversion of NO remained perfectly selective in the sense that only $\mathrm{N}_{2}$ and no $\mathrm{NO}_{2}$ or $\mathrm{N}_{2} \mathrm{O}$ were formed (Fig $4 \mathrm{C}$ and D). 
The conversion of $\mathrm{NO}$ to $\mathrm{NO}_{2}$ by $\mathrm{O}_{2}$ was determined in the absence of methane as a function of the reaction temperature. The results are shown in Fig. 5. The thermodynamic equilibrium allows high conversions below about $700 \mathrm{~K}$ (Fig. 5, dotted curve). When the catalyst was replaced by quartz wool the NO conversion became very low $(<2 \%)$ suggesting that catalyst is needed to facilitate the reaction. In line with expectations $[11,37,38]$ the catalysts containing Co-oxide were very active (Fig. 5A and 5B). The conversion curves pass through maximum. The kinetic control is removed by increasing the reaction temperature up to about $650 \mathrm{~K}$. If temperature is further increased the thermodynamic control becomes effective decreasing the conversion limit $[11,38]$. The zeolite H-ZSM-5 showed significantly lower NO-COX activity than the zeolite $\mathrm{Co}^{\mathrm{SSR}}, \mathrm{H}-\mathrm{ZSM}-5$ sample, containing cobalt oxide (Fig. 5A). Nevertheless, in accordance with earlier results [19,22], the reaction proceeded also on the Brønsted acid sites. Virtually the same conversion curve was obtained using either $\mathrm{Co}^{\mathrm{IE}}, \mathrm{H}-\mathrm{ZSM}-5$ or H-ZSM-5 catalyst (Fig. 5A), which finding substantiates that the $\mathrm{Co}^{2+}$ lattice cations of the zeolites do not contribute to the NO-COX activity. In line with this and with the results of Kaucky et al. [22], significantly lower conversions were observed over $\mathrm{Co}^{\mathrm{IE}}, \mathrm{H}-\mathrm{M}$ than over $\mathrm{Co}^{\mathrm{SSR}}, \mathrm{H}-\mathrm{M}$ (Fig. 5B).

We noticed that under NO-SCR conditions the catalytic function, which accelerates $\mathrm{NO}$ oxidation by $\mathrm{O}_{2}$ to $\mathrm{NO}_{2}$ speeds up also the reaction generating $\mathrm{N}_{2}$. As it was substantiated before $[9,20-22]$ this finding also supports the opinion that $\mathrm{NO}_{2}$ is an intermediate of the NOSCR process. In order to provide clear evidence for this the NO conversion by $\mathrm{O}_{2}$ was studied as a function of space time with and without methane in the reacting gas mixture (Fig. 6). As the space time was increased in absence of methane, the steady-state $\mathrm{NO}_{2}$ concentration in the reactor effluent got closer and closer to its equilibrium value at the selected temperature (Fig. $6 \mathrm{~A})$. In the presence of methane the $\mathrm{NO}$ was converted both to $\mathrm{NO}_{2}$ and $\mathrm{N}_{2}$. As a function of space time the conversion to $\mathrm{N}_{2}$ steadily increased whereas the conversion to $\mathrm{NO}_{2}$ passed through a maximum (Fig. 6B). This is typical concentration vs. space time profile of consecutive reactions, suggesting that the conversion of $\mathrm{NO}$ to $\mathrm{N}_{2}$ occurs through $\mathrm{NO}_{2}$ intermediate. The dashed curve in Fig. $6 \mathrm{~B}$ was obtained as the $\mathrm{N}_{2}$ equivalent of the methane induced $\mathrm{NO}_{2}$ loss, which was obtained as the difference of the $\mathrm{NO}$ conversions to $\mathrm{NO}_{2}$ in absence (Fig.6A) and presence(Fig. 6B) of methane in the reacting gas mixture at the corresponding space times. This calculated curve runs together with the measured $\mathrm{N}_{2}$ formation curve at space times below about $0.1 \mathrm{sec}$ (Fig. 6B), showing that the $\mathrm{N}_{2}$ formed in the NO-SCR reaction comes quantitatively from the conversion of $\mathrm{NO}_{2}$ produced in the NO$\mathrm{COX}$ reaction. At higher space times, however, the measured conversion to $\mathrm{N}_{2}$ begins to 
exceed the $\mathrm{N}_{2}$ equivalent of the corresponding $\mathrm{NO}_{2}$ loss (Fig. 6B). The most probable reason is that the NO-COX reaction is faster in the presence of methane than in its absence because the $\mathrm{CH}_{4} / \mathrm{NO}-\mathrm{SCR}$ reaction, consuming $\mathrm{NO}_{2}$, keeps the steady state $\mathrm{NO}_{2}$ concentration further away from the equilibrium concentration. This enhanced $\mathrm{NO}_{2}$ formation rate results in higher $\mathrm{NO}$ conversion to $\mathrm{N}_{2}$ than that, predicted for the given space time by the calculated $\mathrm{NO}_{2}$ loss.

\subsection{Operando DRIFTS-MS examinations}

\subsubsection{Surface species from adsorption of $\mathrm{NO} \mathrm{O}_{2}$ mixture}

DRIFT spectra obtained from adsorption of $\mathrm{NO} / \mathrm{O}_{2}$ gas mixture on $\mathrm{H}$-form zeolite ZSM-5 and mordenite, and on their cobalt modified derivatives at $573 \mathrm{~K}$ are shown in Figs. 7 and 8. The adsorption involves interaction between the reactants, the products, and the adsorption sites of the zeolite sample. All bands of the obtained adsorbed species were weaker at higher temperatures, and disappeared upon He flush at $773 \mathrm{~K}$ (not shown). These results indicate that weakly and reversibly bound species were formed.

The spectral features developed over H-zeolite samples were interpreted by the overall process of Eq. (2) [39]:

$2 \mathrm{H}^{+} \mathrm{Z}^{-}+\mathrm{NO}+\mathrm{NO}_{2} \leftrightarrows 2 \mathrm{NO}^{+} \mathrm{Z}^{-}+\mathrm{H}_{2} \mathrm{O}$

where $\mathrm{Z}^{-}$represents a segment of the zeolite framework, carrying one negative charge.

On the spectrum of zeolite H-ZSM-5 bands appeared at 2125 and $1640 \mathrm{~cm}^{-1}$ (Fig. 7B, spectrum (a)). These bands stem from the $v_{\mathrm{NO}}$ and $\delta_{\mathrm{H}_{2} \mathrm{O}}$ vibrations of zeolite-bound nitrosonium ions $\left(\mathrm{NO}^{+}\right)$and water, respectively [39]. The formation of these species was accompanied by the consumption of Brønsted acid hydroxyl groups, as indicated by the negative $v_{\mathrm{OH}}$ band at $3600 \mathrm{~cm}^{-1}$ (Fig. 7A, spectrum (a)).

The adsorption on the $\mathrm{H}-\mathrm{M}$ sample can be described similarly. The $\mathrm{NO}^{+}$species gave a broad characteristic band around $2210 \mathrm{~cm}^{-1}$, whereas a weak $\delta_{\mathrm{H}_{2} \mathrm{O}}$ band of water is discernible at about $1630 \mathrm{~cm}^{-1}$ (Fig. 8B, spectrum (a)). The adsorbed $\mathrm{H}_{2} \mathrm{O}$ also generated three broad bands, the so called ABC triad, around 2860, 2380, and $1700 \mathrm{~cm}^{-1}$ (only the latter two are discernible in the shown frequency range), which are due to H-bonding between adsorbed water and acidic $\mathrm{OH}$-groups [16,40]. The H-mordenite has two kinds of bridged hydroxyl groups: one, located in main channels and another in the side pockets, giving $\mathrm{v}_{\mathrm{OH}}$ bands at 
3610 and $3575 \mathrm{~cm}^{-1}$, respectively (vide infra). In a previous study [16], it was shown that $\mathrm{NO}^{+}$ in the main channels and the side pockets has different vibration frequencies giving a $v_{\mathrm{NO}}$ band around 2170 and $2210 \mathrm{~cm}^{-1}$, respectively. The negative $v_{\mathrm{OH}}$ band in the difference spectrum at $3575 \mathrm{~cm}^{-1}$ and the $v_{\mathrm{NO}^{+}}$frequency suggests that under the applied experimental conditions the dehydroxylation and $\mathrm{NO}^{+}$formation took place mainly in the side pockets of the H-mordenite (Fig. 8, spectrum (a)). We note here that the intensity loss of the $v_{\mathrm{OH}}$ band is partly due to the replacement of the zeolite protons by $\mathrm{NO}^{+}$and to some extent also due to the mentioned H-bond interaction of the hydroxyl groups and water.

If the zeolite contains both $\mathrm{H}^{+}$and $\mathrm{Co}^{2+}$ ions the $\mathrm{NO} / \mathrm{O}_{2}$ adsorption gives not only the bands discussed above but additional bands that must be attributed to the involvement of the cobalt ions in the adsorption process. The heterolytic water split on $\mathrm{Co}^{2+}$ sites $\left(\mathrm{Co}^{2+} \mathrm{Z}_{2}^{-}+\mathrm{H}_{2} \mathrm{O}\right.$ $\left.\leftrightarrows[\mathrm{Co}-\mathrm{OH}]^{+} \mathrm{Z}^{-}+\mathrm{H}^{+} \mathrm{Z}^{-}\right)$generate hydroxyl groups, not present in the H-form zeolites $[17,25,41]$. Notice the new bands at 3670 and $3650 \mathrm{~cm}^{-1}$ in the spectra of $\mathrm{Co}^{\mathrm{IE}}, \mathrm{H}-\mathrm{ZSM}-5$ and $\mathrm{Co}^{\mathrm{IE}}$,H-M sample, respectively (Fig. 9). Latter bands come from the $v_{\mathrm{OH}}$ vibration of a cobaltbound hydroxyl groups. Cobalt ion-exchange resulted in an intensity decrease of the $v_{\mathrm{OH}}$ band of the acidic $\mathrm{OH}$-groups. (The $\mathrm{H}-$ and $\mathrm{Co}^{\mathrm{IE}}, \mathrm{H}-\mathrm{ZSM}-5$ presents additional $v_{\mathrm{OH}}$ bands at 3738 and $3700 \mathrm{~cm}^{-1}$ due to external and internal terminal Si-OH groups, respectively, whereas the $\mathrm{OH}$-groups attached to extra framework aluminum species give characteristic band at 3655 $\mathrm{cm}^{-1}$ [42]. These species have no relevance to present discussion.)

The new features on the spectrum obtained from adsorption of $\mathrm{NO} / \mathrm{O}_{2}$ mixture on the $\mathrm{Co}^{\mathrm{IE}}$,H-ZSM-5 catalyst are the negative $\mathrm{v}_{\mathrm{OH}}$ band at about $3670 \mathrm{~cm}^{-1}$ (Fig. 7A, spectrum (c)), the band at $\sim 1570 \mathrm{~cm}^{-1}$ with shoulders at $\sim 1600$ and $1520 \mathrm{~cm}^{-1}$, and bands in the $1750-$ $1950 \mathrm{~cm}^{-1}$ range (Fig. 7B, spectrum (c)). Latter bands are usually attributed to different nitrosyls and dinitrosyls of cobalt ions (vide infra) [43]. The negative $v_{\mathrm{OH}}$ band indirectly indicates the involvement of $[\mathrm{Co}-\mathrm{OH}]^{+}$sites in the formation of surface species giving the new positive absorption bands at about $1570 \mathrm{~cm}^{-1}$ assigned to $\mathrm{NO}_{\mathrm{x}}^{-}$species, particularly to zeolite-bound nitrate species $[44,45]$. Generally, the appearance of the $\mathrm{NO}_{3}{ }^{-}$bands is paralleled by the enhanced intensity of the $\mathrm{NO}^{+}$band, suggesting that the processes, described by Eqs. (3) and (4), prevail [15,44-46].

$$
\mathrm{Co}^{2+} \mathrm{Z}_{2}^{-}+2 \mathrm{NO}_{2} \leftrightarrows\left[\mathrm{Co}-\mathrm{NO}_{3}\right]^{+} \mathrm{Z}^{-}+[\mathrm{NO}]^{+} \mathrm{Z}^{-}
$$




$$
[\mathrm{Co}-\mathrm{OH}]^{+} \mathrm{Z}^{-}+\mathrm{H}^{+} \mathrm{Z}^{-}+2 \mathrm{NO}_{2} \leftrightarrows\left[\mathrm{Co}_{-} \mathrm{NO}_{3}\right]^{+} \mathrm{Z}^{-}+[\mathrm{NO}]^{+} \mathrm{Z}^{-}+\mathrm{H}_{2} \mathrm{O}
$$

In contact with $\mathrm{NO} / \mathrm{O}_{2}$ gas flow the $\mathrm{Co}^{\mathrm{IE}}, \mathrm{H}-\mathrm{M}$ catalyst showed similar spectra as the $\mathrm{Co}^{\mathrm{IE}}, \mathrm{H}-\mathrm{ZSM}-5$ catalyst (cf. Fig. 7 and 8, spectra (c)). The found minor differences reflect the structural differences of the zeolites. The $\mathrm{NO}^{+}$, formed in the latter catalyst, gave a single band at $2125 \mathrm{~cm}^{-1}$, whereas that formed in the former one gave a pair of bands at 2170 and $2210 \mathrm{~cm}^{-1}$ (cf. Figs. 7B and 8B, spectra(c)). It is obvious that the two bands stem from two kinds of $\mathrm{NO}^{+}$species, which must be related to two kinds of adsorption sites [16]. It was shown that the cobalt population of the cation positions of mordenite depends on the degree of ion exchange. At low exchange degree $\left(\mathrm{Co} / \mathrm{Al}_{\mathrm{F}}<\sim 0.1\right)$ the cobalt ions take positions in the side pockets, whereas at higher exchange degrees $\left(\mathrm{Co} / \mathrm{Al}_{\mathrm{F}}>0.1\right)$ positions are occupied also in the main channels [47]. The $\mathrm{Co} / \mathrm{Al}_{\mathrm{F}}$ ratio in $\mathrm{Co}^{\mathrm{EE}}, \mathrm{H}-\mathrm{M}$ is 0.175 (Table 1). Both $v_{\mathrm{OH}}$ component bands of the $\mathrm{Co}^{\mathrm{IE}}, \mathrm{H}-\mathrm{M}$ samples is weaker than the corresponding bands of the parent H-M sample (Fig. 9B). Data suggest that the framework charge of mordenite is balanced by cobalt ions and protons both in the side pockets and in the main channels. The $v_{\mathrm{NO}}{ }^{+}$band at $2170 \mathrm{~cm}^{-1}$, obtained from the $\mathrm{NO} / \mathrm{O}_{2}$ adsorption over $\mathrm{Co}^{\mathrm{IE}}, \mathrm{H}-\mathrm{M}$, suggested that $\mathrm{NO}^{+}$species was formed in the main channels (Fig. 8B, spectrum (c)). Together with the appearance of the $v_{\mathrm{NO}^{+}}$band, bands of nitrate species appeared in the $1650-1500 \mathrm{~cm}^{-1}$ frequency range. The negative $v_{\mathrm{OH}}$ band at $3655 \mathrm{~cm}^{-1}$ (Fig. 8A, spectrum (c)) indirectly indicates the involvement of $[\mathrm{Co}-\mathrm{OH}]^{+}$species in the simultaneous formation of $\mathrm{NO}^{+}$and $\mathrm{NO}_{3}{ }^{-}$ions.

The bands in the $1750-1950 \mathrm{~cm}^{-1}$ range are usually attributed to different nitrosyls and dinitrosyls of cobalt ions [43]. The pair of bands at 1805 and $\sim 1900 \mathrm{~cm}^{-1}$ (Fig. 7B) were assigned to the symmetric and asymmetric $v_{\mathrm{NO}}$ vibrations of $\mathrm{Co}^{2+}$-dinitrosyl species $[6,7,44,48]$. As we discussed in a recent publication [5], the assignment of the band at $1932 \mathrm{~cm}^{-1}$ (Fig. 7B) is less straightforward. Briefly, it was attributed either to $\mathrm{Co}^{2+}$ mononitrosyl [6,7], or to $\mathrm{Co}^{3+}$-mononitrosyl in Co-ZSM-5 [44,48]. It was emphasized, however, that latter species must carry an oxygen ligand that lowers the charge on the cobalt $[49,50]$. It was argued that it is highly improbable that bare $\mathrm{Co}^{3+}$ ions could neutralize three distant negative charges of the zeolite having high framework Si to Al ratio (>15). The oxygen-carrying $\mathrm{Co}^{3+}$ was expected to get reduced at lower temperature than the $\mathrm{Co}^{2+}$ ions $[10,11,25,27,28]$. The $\mathrm{H}_{2}$-TPR results, however, showed that our $\mathrm{Co}^{\mathrm{IE}}, \mathrm{H}-\mathrm{ZSM}-5$ sample contains only a minor amount of cobalt species reducible below $1073 \mathrm{~K}$ (Table 2). Therefore, 
it seems likely that this sample contains mainly hard-to-reduce $\mathrm{Co}^{2+}$ species and the band at $1932 \mathrm{~cm}^{-1}$ can be assigned to $\mathrm{Co}^{2+}$-mononitrosyl [6,7].

When Co is present predominantly in the form of Co-oxide clusters (shown by $\mathrm{H}_{2}$-TPR and XPS) and only negligible amount belongs to the zeolite lattice, as in the $\mathrm{Co}^{\mathrm{SSR}}, \mathrm{H}-$

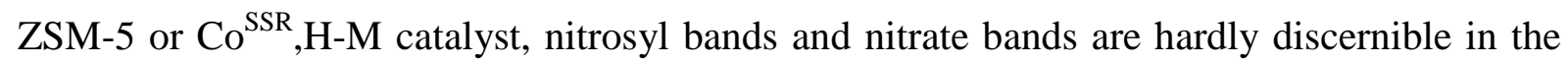
DRIFT spectrum (Fig. 7B and 8B, spectrum (b)). These results are in accordance with the observation that nitrosyls and nitrate species can form on zeolite cobalt ions, whereas such surface species are not formed on Co-oxide clusters [25,49]. Since NO adsorption and the process of Eq. (3) hardly proceed on Co-oxide clusters, the spectra obtained on the $\mathrm{Co}^{\mathrm{SSR}}, \mathrm{H}-\mathrm{ZSM}-5$ and $\mathrm{Co}^{\mathrm{SSR}}, \mathrm{H}-\mathrm{M}$ catalysts in contact with $\mathrm{NO} / \mathrm{O}_{2}$ mixture closely resemble to those obtained for the H-ZSM-5 and H-M, respectively (cf. spectra (a) and (b) in Fig. 7 and 8). These results substantiate that only the process according to Eq. (2) prevails on these sample. Similarly, the spectra obtained for the $\mathrm{Co}^{\mathrm{SSR}}, \mathrm{Co}^{\mathrm{IE}}, \mathrm{H}-\mathrm{ZSM}-5$ and $\mathrm{Co}^{\mathrm{SSR}}, \mathrm{Co}^{\mathrm{IE}}, \mathrm{H}-\mathrm{M}$ samples correspond to those obtained for the $\mathrm{Co}^{\mathrm{IE}}, \mathrm{H}-\mathrm{ZSM}-5$ and $\mathrm{Co}^{\mathrm{IE}}, \mathrm{H}-\mathrm{M}$ samples (cf. Fig. 7, spectra (c) and (d), and Fig. 8, spectra (c-e)) indicating that processes of NO oxidation and formation of $\mathrm{NO}^{+}$and $\mathrm{NO}_{3}^{-}$(Eqs. (2) and (3)) proceed on these samples. Note, however that the $\mathrm{NO}_{3}{ }^{-}$bands $\left(1600-1500 \mathrm{~cm}^{-1}\right)$ of the catalysts show substantial intensity difference. The surface concentration of the $\mathrm{NO}_{3}{ }^{-}$species is higher on the catalysts containing both Co-oxide and zeolite $\mathrm{Co}^{2+}$ ions as compared to those containing predominantly the latter cobalt sites. Results suggest that the rate of the process according to Eq. (3) is higher in the presence of Co-oxide, promoting the NO-COX reaction.

\subsubsection{Reaction of methane with the surface species from $\mathrm{NO} / \mathrm{NO}_{2}$}

The transient response of the catalytic system comprising of $\mathrm{Co}^{\mathrm{SSR}}, \mathrm{Co}^{\mathrm{IE}}, \mathrm{H}-\mathrm{M}(1)$ catalyst and $\mathrm{NO} / \mathrm{O}_{2} / \mathrm{He}$ reactant flow was studied at different temperatures. The steady state of the system was disturbed by suddenly changing the $\mathrm{NO} / \mathrm{O}_{2} / \mathrm{He}$ gas flow to a flow of $\mathrm{CH}_{4} / \mathrm{NO} / \mathrm{O}_{2} / \mathrm{He}$, while the partial pressures of $\mathrm{NO}$ and $\mathrm{O}_{2}$ were kept unchanged. The transient change of the concentrations of different surface species (monitored by DRIFT spectroscopy) and effluent composition (monitored by MS) are shown in Fig. 10 and 11, respectively. At steady state in $\mathrm{NO} / \mathrm{O}_{2} / \mathrm{He}$ reactant flow at $673 \mathrm{~K}$ or $723 \mathrm{~K}$, practically the same surface species can be observed than those at $573 \mathrm{~K}$ (cf. Fig. 8B, spectrum (d) and top spectra in Fig. 10). However, the intensity of the characteristic bands of $\mathrm{NO}^{+}\left(\sim 2220\right.$ and $\left.2170 \mathrm{~cm}^{-1}\right)$ and nitrate $\left(1600-1500 \mathrm{~cm}^{-1}\right)$ was lower at higher reaction temperatures suggesting lower steady state concentration of these species due to the reversibility of the processes according to Eqs. 
(2) and (3). The $\mathrm{Co}^{2+}$-NO species appear to be thermally more stable as indicated by the less significant intensity drop of the band at $1937 \mathrm{~cm}^{-1}$.

The concentration of the above species decreased in time upon switching from $\mathrm{NO} / \mathrm{O}_{2} / \mathrm{He}$ to $\mathrm{CH}_{4} / \mathrm{NO} / \mathrm{O}_{2} / \mathrm{He}$ flow until they reached their new, lower steady state concentrations (Fig. 10, bottom spectra). The changes are faster at higher reaction temperature. The consumption of $\mathrm{NO}_{3}{ }^{-}$species in the $\mathrm{CH}_{4} / \mathrm{NO}-\mathrm{SCR}$ reaction is accompanied by the consumption of $\mathrm{NO}^{+}$species as it is clearly shown by the concomitant intensity drop of the corresponding bands (Fig. 10). Note that those $\mathrm{NO}^{+}$species were consumed predominantly in the reaction (band at $2170 \mathrm{~cm}^{-1}$ ), which were formed together with nitrate species in the main channels with the involvement on $\mathrm{Co}^{2+}$ sites. In a former study [18], we have shown that the $\mathrm{NO}^{+}$alone cannot react with methane. Conversely, the $\mathrm{NO}^{+}$, formed together with $\mathrm{NO}_{3}{ }^{-}$(Eq. (3)), was also consumed together in the NO-SCR reaction, which is in full agreement with the results obtained using In,H-M catalysts [18]. No doubt, however, that the surface concentration of $\mathrm{NO}^{+}$must have been decreased also, because the product water of the NO-SCR reaction shifted the equilibrium of Eq. (2). In line with the NO-SCR activity of the catalyst, the NO-SCR products such as $\mathrm{CO}_{2}$ (bands at 2362 and $2332 \mathrm{~cm}^{-1}$ in the IR spectra, also detected by MS) and $\mathrm{N}_{2}$ (detected by MS) were discernible. Some water formed was retained by the zeolite matrix and the corresponding $\delta_{\mathrm{H}_{2} \mathrm{O}}$ band at $1630 \mathrm{~cm}^{-1}$ gradually increased in time until its steady state concentration was reached. In agreement with above observations, earlier studies also substantiated that surface nitrates formed on the Co sites are reactive with methane and can induce $\mathrm{N}_{2}$ formation $[17,44,45]$. It was, however, excluded that different cobalt nitrosyls were active intermediates of the NO-SCR reaction [44,45]. It was also shown that the Co-mononitrosyl giving the band at $1937 \mathrm{~cm}^{-1}$ is particularly sensitive to water [44]. The intensity drop of this band (Fig. 10) is, therefore, due to the displacement of the nitrosyl species by water formed during the SCR reaction. This is clearly supported by the fact that the intensity of the nitrosyl band was hardly affected initially, then declined quickly as the intensity of the $\delta_{\mathrm{H}_{2} \mathrm{O}}$ band of adsorbed water at $1630 \mathrm{~cm}^{-1}$ increased after about $3 \mathrm{~min}$ reaction time, when the other reaction products have already reached their steady state concentrations (Fig. 11). Thus, in agreement with earlier findings [44,45], we also exclude that mononitrosyl species could play any role in the NO-SCR mechanism.

The steady state concentrations of $\mathrm{NO}_{2}$ (formed in $\mathrm{NO}-\mathrm{COX}$ reaction) and $\mathrm{N}_{2}$ (formed in $\mathrm{CH}_{4} / \mathrm{NO}-\mathrm{SCR}$ reaction) are in good agreement with those obtained in corresponding microreactor experiments under the same reaction conditions (Fig. 4C and 5B). At higher temperature higher is the rate of $\mathrm{NO}^{+} / \mathrm{NO}_{3}{ }^{-}$conversion (Fig. 10) and the composition of the 
reactor effluent reaches its steady state also more quickly (Fig. 11). The rate constant of the $\mathrm{CH}_{4} / \mathrm{NO}-\mathrm{SCR}$ reaction increases more rapidly with increasing temperature than that of the NO-COX reaction as indicated by the total vanish of $\mathrm{NO}_{2}$ reaction intermediate from the reactor effluent at $723 \mathrm{~K}$ (cf. Figs. $11 \mathrm{~A}$ and 11B). The initial overshoot of the $\mathrm{N}_{2}$ and $\mathrm{CO}_{2}$ concentrations comes from the higher initial surface concentration of the nitrate than in the new steady state, being approached.

\section{Discussion}

\subsection{The Co species of the catalysts}

The conventional liquid phase ion-exchange (IE) of H-zeolite with cobalt(II)nitrate solution and subsequent dehydration treatment of the sample resulted in Co-zeolites containing hard-to-reduce $\mathrm{Co}^{2+} /[\mathrm{Co}-\mathrm{OH}]^{+}$cations as dominant cobalt species, occupying ionexchange positions in the zeolite lattice. The treatment led also to formation of minor amount of Co-oxo species within the zeolite channels, most probably mono-, bi-, or polynuclear, cationic oxo- and hydroxo complexes $\left(\mathrm{Co}_{\mathrm{x}} \mathrm{O}_{\mathrm{y}} \mathrm{H}_{\mathrm{z}}{ }^{\mathrm{n}+}\right.$, where $\mathrm{n}=1$ or 2$)$ [29,51,52]. Their formation is favored at higher Co exchange levels and lower framework Si/Al ratios [29,49,51]. Accordingly, the Co-oxo species account for about $16 \%$ and $4 \%$ of the total Co content of the mordenite and ZSM-5 sample, respectively.

The solid state reaction (SSR) between $\mathrm{H}$-zeolite and cobalt acetate resulted in catalysts containing Co-oxide clusters (mostly $\mathrm{Co}_{3} \mathrm{O}_{4}$ particles) mainly on the outer surface of the zeolite crystallites. These species do not adsorb NO [25,49]. Therefore, the appearance of $\mathrm{Co}^{2+}$-NO band in the infrared spectra (Figs. 7 and 8) suggests that a minor fraction of cobalt occupied lattice positions as $\mathrm{Co}^{2+}$ cations in the zeolite structure. If $\mathrm{Co}, \mathrm{H}-$ form zeolites were exposed to similar SSR the obtained catalysts contained cobalt both as zeolite cations and also as Co-oxide clusters out of the zeolite structure. The XPS measurements confirmed the coexistence of $\mathrm{Co}^{2+}$ ions and Co-oxide clusters in these catalysts. The SSR did hardly affect the lattice cations.

\subsection{Catalytic functions of the Co species}

There is ample of evidence that the lattice $\mathrm{Co}^{2+}$-ions are active in the $\mathrm{N}_{2}$ forming $\mathrm{CH}_{4} / \mathrm{NO}-\mathrm{SCR}$ reaction (Figs. $3 \mathrm{~A}$ and $4 \mathrm{~A}$ ) $[3,11,22,26,33,41,51,53]$ but do not contribute to 
the NO-COX activity of the catalyst (Fig. 5) [3,24,26,33]. Indovina et al. found linear correlation between catalytic activity and concentration of $\mathrm{Co}^{2+}$ ions in both Co-ZSM-5 [33] and Co-mordenite [41,53] catalysts. The findings of the present study seem to be in accordance with this observation (Figs. 3A and 4A). However, regarding such correlations, it should be noted that a small fraction of cobalt can get in the sample in the ion exchange process without becoming zeolite cation (vide supra). Moreover, the $\mathrm{Co}^{2+}$ ions can have significantly different catalytic activity in different cation positions of the zeolite structure. In mordenite, for instance, the $\mathrm{Co}^{2+}$ ions show activity only in the main channels, i.e., in the socalled $\mathrm{E}$ or $\alpha$ sites $[22,41,47,53]$. The main channels start to fill up by cations at an exchange level of $\mathrm{Co} / \mathrm{Al}_{\mathrm{F}}>0.1$ [47]. Therefore, it can be estimated that in the $\mathrm{Co}^{\mathrm{IE}}, \mathrm{H}-\mathrm{M}$ sample only about $36 \%$ of the total cobalt content can be considered active. In contrast, all the cobalt of the Co,H-ZSM-5 catalysts are active in the SCR reaction [54,55]. Indeed, the NO conversion over the $\mathrm{Co}^{\mathrm{IE}}, \mathrm{H}-\mathrm{M}$ catalyst was only about twice as high than over the $\mathrm{Co}^{\mathrm{IE}}, \mathrm{H}-\mathrm{ZSM}-5$ catalyst, although its Co content was 5.7 times higher (cf. Figs. 3A and 4A).

The role of zeolite $\mathrm{Co}^{2+}$ ions in the NO-SCR is still matter of debate. It was argued that the reaction involving several molecules and reaction steps is highly unlikely to proceed on isolated $\mathrm{Co}^{2+}$ sites. The catalytic activity of these cobalt cations was also questioned because of their "redox-inactive" nature. Therefore, not the zeolite cations but small Co-oxide microaggregates in the zeolite pores were suggested to be the real active sites $[29,30]$. The found correlation between the catalytic activity and the $\mathrm{Co}^{2+}$ concentration and the absence of evidence for the presence of oxide microaggregates at low cobalt loadings strongly questions this notion [33,41,51,53]. Intrapore Co-oxo species were observed only at higher Co loadings. The amount of such species increased exponentially with the Co content, whereas the NOSCR activity still increased linearly, suggesting that these species alone could not be the active sites [51,53]. Above we have also shown that there is good correlation between the amount of active $\mathrm{Co}^{2+}$ ions and catalytic activity of mordenite and ZSM-5 catalysts. These results support that lattice $\mathrm{Co}^{2+}$ sites have key role in the NO-SCR reaction.

As it was reported earlier [11,22,26,29,33], the Co-oxide clusters promote the $\mathrm{NO}_{2}$ generating NO-COX reaction (Fig. 5), but not the $\mathrm{N}_{2}$-forming $\mathrm{CH}_{4} / \mathrm{NO}-\mathrm{SCR}$ reaction step of the NO-SCR process (Fig. 3B and 4B). Over the $\mathrm{Co}^{\mathrm{SSR}}, \mathrm{H}$-zeolites no nitrogen formation was observed below $700 \mathrm{~K}$. The activity could turn up at high temperature due to the presence of minor amount of $\mathrm{Co}^{2+}$ that eventually got in the zeolite structure during SSR. It is well documented that the Co-oxide-like species are able to promote the oxidation of $\mathrm{NO}$ to $\mathrm{NO}_{2}$ $[3,22,24,26,31]$. As others [19,22], we found that also the Brøsted acid sites can induce this 
oxidation process, but at significantly lower rate than the Co-oxide clusters (Fig. 5). Thus, introduction of Co-oxide clusters into Co-exchanged zeolites promoted the generation of $\mathrm{NO}_{2}$. The accelerated NO-SCR reaction is attributed to this catalytic effect (Figs. 3C and 4C). Similar promoting effect was already suggested to contribute to the NO-SCR activity of different Co and Pd catalysts [22,26,37,56].

The Co-oxo species in the Co-zeolites can be also with negative effect on the NO-SCR activity. It should be noted that the $\mathrm{Co}_{3} \mathrm{O}_{4}$, which was the main Co species in our catalysts, promote also the undesired methane combustion [3,24,27,29,33]. This reaction can decrease the selectivity of NO reduction by consuming the reducing agent methane. The relative rate of the preferred or the adverse processes depends on the reaction temperature and the cobalt oxide content as it is shown by Figs. 4C and 4D. Over about $700 \mathrm{~K}$ the methane combustion became the prevailing reaction, whereas below this temperature the promoting effect of the oxide prevails. These results suggest that the NO-COX and the $\mathrm{CH}_{4} / \mathrm{NO}-\mathrm{SCR}$ activities of the catalyst should be properly balanced in order to maximize $\mathrm{N}_{2}$ selectivity.

\subsection{Cooperation of catalytic functions}

The interplay of active sites catalyzing the NO-COX reaction (Co-oxide species) and the $\mathrm{N}_{2}$-forming $\mathrm{CH}_{4} / \mathrm{NO}-\mathrm{SCR}$ reaction ( $\mathrm{Co}^{2+}$ sites) seems to be required to get NO-SCR reaction. The promotional effect of Co-oxo species is manifested in their ability to accelerate the NO-COX, i.e., the oxidation of $\mathrm{NO}$ to $\mathrm{NO}_{2}$. In absence of such species the NO-COX reaction proceeds on Brønsted acid sites at a lower rate (Fig. 5A). Results also suggest that high $\mathrm{N}_{2}$ selectivity requires quick consumption of $\mathrm{NO}_{2}$ by the $\mathrm{N}_{2}$-forming $\mathrm{CH}_{4} / \mathrm{NO}-\mathrm{SCR}$ reaction. Latter reaction becomes high enough over about $700 \mathrm{~K}$, where the Co-oxide promoted catalysts became fully selective for $\mathrm{N}_{2}$ (Figs. 3C and 4C). Below this temperature, the $\mathrm{NO}_{2}$ formed in the NO-COX reaction is not completely consumed and appears in the gas phase as generally observed for Co-zeolites containing Co-oxide species in addition to ionexchanged $\mathrm{Co}^{2+}$ ions $[10,11,22,29]$. The appearance of $\mathrm{NO}_{2}$ in the product mixture led some authors to question the role of $\mathrm{NO}_{2}$ as important NO-SCR intermediate [10-12]. It was argued, that gas phase $\mathrm{NO}_{2}$ was formed from adsorbed $\mathrm{NO}_{\mathrm{x}}$ species at lower reaction temperatures in an undesired parallel reaction, where the thermodynamics favored its formation. It was suggested that the reaction became selective towards $\mathrm{N}_{2}$ only in the higher reaction temperature range where the formation of $\mathrm{NO}_{2}$ was thermodynamically limited and adsorbed $\mathrm{NO}_{\mathrm{x}}$ species were consumed only in the reaction giving $\mathrm{N}_{2}$. In agreement with earlier findings 
[9] our results strongly suggest that $\mathrm{NO}_{2}$ was consumed in the $\mathrm{N}_{2}$-forming $\mathrm{CH}_{4} / \mathrm{NO}-\mathrm{SCR}$ reaction. This becomes obvious if we compare the $\mathrm{NO}_{2}$ concentration in the reactor effluent when methane is present or absent in the feed (cf. Figs. 3C and 5A or Figs. 4C and 5B). The methane reduces the $\mathrm{NO}$ conversion to $\mathrm{NO}_{2}$. The conversion curves provide evidence that $\mathrm{NO}_{2}$ is reaction intermediate (Fig. 6). At low space times $\left(<0.1\right.$ s), where the $\mathrm{NO}_{2}$ concentration is still far from its equilibrium concentration, the actual $\mathrm{NO}$ conversion to $\mathrm{N}_{2}$ was equal with the $\mathrm{N}_{2}$ amount, equivalent with the $\mathrm{NO}_{2}$ formed in the $\mathrm{NO}-\mathrm{COX}$ in the absence of methane in the reactant gas. At higher space times the conversion to $\mathrm{NO}_{2}$ passes through maximum as usually happens with the intermediate of a consecutive reaction. These observations substantiate that the $\mathrm{N}_{2}$-forming $\mathrm{CH}_{4} / \mathrm{NO}-\mathrm{SCR}$ reaction is related to the $\mathrm{NO}_{2}$ forming NO-COX reaction and $\mathrm{NO}_{2}$ is a key intermediate [9,20-22]. It is important to note, that this latter reaction also requires a catalyst (Fig. 5), although the thermodynamics allow high $\mathrm{NO}_{2}$ concentration even at $673 \mathrm{~K}$. Indeed, it is well known that $\mathrm{NO}$ is easily oxidized to $\mathrm{NO}_{2}$ with $\mathrm{O}_{2}$ in the gas phase $\left(2 \mathrm{NO}+\mathrm{O}_{2} \leftrightarrows 2 \mathrm{NO}_{2}\right)$ at room temperature; however, $\mathrm{NO}_{2}$ formation quickly drops to zero at about $573 \mathrm{~K}$ and does not proceed at all even at higher temperatures without a catalyst [19]. This is due to the fact, that the rate of the reaction is controlled by a pre-equilibrium, in which $\mathrm{N}_{2} \mathrm{O}_{2}$ is formed $\left(\mathrm{NO}+\mathrm{NO} \leftrightarrows \mathrm{N}_{2} \mathrm{O}_{2} ; \mathrm{N}_{2} \mathrm{O}_{2}+\mathrm{O}_{2} \rightarrow\right.$ $2 \mathrm{NO}_{2}$ ). Either low temperature or catalyst is needed to promote the conversion of $\mathrm{NO}$ by $\mathrm{O}_{2}$.

The activity of the $\mathrm{Co}^{2+} /[\mathrm{Co}-\mathrm{OH}]^{+}$sites in the NO-SCR reaction is clearly related to their ability to form surface nitrate species (vide infra). This reaction requires $\mathrm{NO}_{2}$ (Eqs. (3) and (4)) $[5,17]$. The steady state $\mathrm{NO}_{3}{ }^{-}$concentration on the zeolite catalyst depends on the relative rates of the $\mathrm{NO}-\mathrm{COX}$ and the $\mathrm{N}_{2}$ forming $\mathrm{CH}_{4} / \mathrm{NO}-\mathrm{SCR}$ reactions (Figs. 7 and 8).

\subsection{Catalytic mechanism}

In harmony with earlier conclusions $[10,12,17,25,44,45]$ the operando DRIFTS results confirm that the nitrate formed on cationic $\mathrm{Co}^{2+} /[\mathrm{Co}-\mathrm{OH}]^{+}$sites participate in the $\mathrm{CH}_{4} / \mathrm{NO}-\mathrm{SCR}$ reaction resulting in $\mathrm{N}_{2}$ formation (Figs. 10 and 11). Catalytic results suggest that this $\mathrm{N}_{2}$-forming reaction proceeds over about $600 \mathrm{~K}$ with a considerable rate (Figs. 3 and 4). The surface nitrate species react with methane giving the active intermediate of the $\mathrm{CH}_{4} / \mathrm{NO}-\mathrm{SCR}$ reaction. The activation of a $\mathrm{C}-\mathrm{H}$ bond in $\mathrm{CH}_{4}$ was substantiated as the rate determining step of the NO-SCR process $[3,9,57]$. In present study, we could not identify the active intermediate because of its fast conversion to SCR product $\mathrm{N}_{2}, \mathrm{CO}_{2}$, and $\mathrm{H}_{2} \mathrm{O}$. It could 
be nitromethane as it is often suggested $[3,6,9]$. Accepting this suggestion, the activation of methane is envisioned as follows:

$\left[\mathrm{Co}-\mathrm{NO}_{3}\right]^{+} \mathrm{Z}^{-}+\mathrm{CH}_{4} \leftrightarrows[\mathrm{Co}-\mathrm{OH}]^{+} \mathrm{Z}^{-}+\mathrm{CH}_{3} \mathrm{NO}_{2}$

The elementary steps of the reaction are presently not known. It has been proposed that the $\mathrm{C}-\mathrm{H}$ bond cleavage, initiated by adsorbed $\mathrm{NO}_{\mathrm{x}}$ species, results in a methyl radical and a hydroxyl radical (or $\mathrm{HONO}, \mathrm{HNO}_{2}$ ], although gas phase methyl radicals could not be detected $[6,9,21,58]$. The involvement of free radicals is not questioned, however, there are strong evidences that the reaction must be initiated by catalyst [20,21,58]. Depending on the catalyst further transformations can generate various surface species, such as, isocyanate $\left(\mathrm{NCO}^{-}\right)$, nitrile $\left(\mathrm{CN}^{-}\right)$, or $\mathrm{NH}_{\mathrm{x}}$ species $\left(\mathrm{NH}_{3}\right.$ or $\left.\mathrm{NH}_{4}{ }^{+}\right)$, which species were also suggested to be the active intermediate of the NO-SCR reaction $[3,4,7,9,13]$. Anyhow, a plausible mechanism has to show that the charge balance of the system is maintained throughout the catalytic cycle (vide infra).

It is often suggested that the active intermediate reacts with gas phase or adsorbed NO or $\mathrm{NO}_{2}$ to give $\mathrm{N}_{2}$ [6-12]. We propose here that the $\mathrm{NO}^{+}$species plays a key role in the $\mathrm{N}_{2^{-}}$ forming reaction step $[5,17,18]$ :

$\mathrm{NO}^{+} \mathrm{Z}^{-}+\mathrm{CH}_{3} \mathrm{NO}_{2} \leftrightarrows \mathrm{N}_{2}+\mathrm{H}^{+} \mathrm{Z}^{-}+\mathrm{H}_{2} \mathrm{O}+\mathrm{CO}_{2}$

The $\mathrm{NO}^{+}$species alone, when formed for instance on Brønsted acid sites (Eq. (2)), cannot initiate the $\mathrm{CH}_{4} / \mathrm{NO}-\mathrm{SCR}$ reaction [18]. However, the surface $\mathrm{NO}^{+}$together with $\mathrm{NO}_{3}{ }^{-}$seems to take part in the NO-SCR reaction $[5,17,18]$. The $\mathrm{NO}^{+}$can react with the intermediate species generated in the reaction of methane and the surface nitrate [5,18]. The formal oxidation state of nitrogen in the $\mathrm{NO}^{+}$and in the mentioned intermediate are 3+ and 3-, respectively, satisfying the criterion of $\mathrm{N}_{2}$ formation from two nitrogen-containing species $[4,58]$. Results of the present study confirm the parallel formation and consumption of $\mathrm{NO}^{+}$ and $\mathrm{NO}_{3}{ }^{-}$species (Fig. 10).

The mechanism, outlined by Scheme 1, provides plausible explanation how the charge balance of the system can be maintained in the catalytic cycle. Note that the reactions according to Eqs. (5) and (6) proceed on $\mathrm{NO}_{3}{ }^{-} / \mathrm{NO}^{+}$ion pairs formed on $\mathrm{Co}^{2+} /[\mathrm{Co}-\mathrm{OH}]^{+}$sites (Eq. (3) and (4)). The reaction of Eq. (1) implies the formation of a water that may come from the reaction of $\mathrm{NO}_{2}$ and $[\mathrm{Co}-\mathrm{OH}]^{+}$sites (Eq. (4)) or by water desorption. 
The water is released that would be in excess to the actual equilibrium coverage of the $\mathrm{Co}^{2+}$ sites by heterolytically dissociated $\mathrm{H}_{2} \mathrm{O}$ molecules [9,52,53]. Higher temperature and higher concentration of $\mathrm{Co}^{2+}$ sites favors water desorption. This process may have importance, because the $\mathrm{NO}_{2}$ activation (Eq. (3)) proceeds in the electrostatic field of $\mathrm{Co}^{2+}$, which is stronger than the field of $[\mathrm{Co}-\mathrm{OH}]^{+}$sites. Thus, formation of $\mathrm{NO}_{3}{ }^{-} / \mathrm{NO}^{+}$ion pairs and the $\mathrm{N}_{2}$-forming reaction might be limited by water desorption and require relatively high temperature $(>650 \mathrm{~K})$ to proceed at a rate comparable to the rate of the $\mathrm{NO}_{2}$-forming $\mathrm{NO}$ COX reaction.

Scheme 1 shows the interplay of the $\mathrm{CH}_{4} / \mathrm{NO}-\mathrm{SCR}$ and the NO-COX activities. If the activation of methane by the surface nitrate is the rate determining step of the NO-SCR reaction, the higher rate of $\mathrm{NO}_{3}{ }^{-} / \mathrm{NO}^{+}$formation leads to a higher rate of the $\mathrm{CH}_{4} / \mathrm{NO}-\mathrm{SCR}$ reaction. The $\mathrm{NO}_{2}$-forming $\mathrm{NO}-\mathrm{COX}$ reaction was significantly faster in the presence of Cooxo species than on Brønsted acid sites. The fast $\mathrm{NO}_{2}$ generation promoted the formation of $\mathrm{NO}_{3}{ }^{-} / \mathrm{NO}^{+}$pairs, thereby, the rate of methane activation and the rate of the whole NO-SCR process.

In the $\mathrm{Co}^{\mathrm{IE}}{ }^{\mathrm{H}} \mathrm{H}$-zeolites, the NO-COX and $\mathrm{CH}_{4} / \mathrm{NO}-\mathrm{SCR}$ activities seem to be well balanced. The activity is low but the $\mathrm{N}_{2}$ selectivity is high in the whole applied temperature range (Figs. 3A and 4A). However, on the Co-oxide promoted $\mathrm{Co}^{\mathrm{IE}}, \mathrm{H}$-zeolite the rate of the $\mathrm{N}_{2}$ forming $\mathrm{CH}_{4} / \mathrm{NO}-\mathrm{SCR}$ reaction matches the increased rate of the $\mathrm{NO}_{2}$-forming NO-COX reaction only over about $700 \mathrm{~K}$ (Figs. 3C and 4C). Below $700 \mathrm{~K}$, the high NO-COX activity and the insufficient $\mathrm{CH}_{4} / \mathrm{NO}-\mathrm{SCR}$ activity of the catalysts result in the appearance of $\mathrm{NO}_{2}$ in the product gas, causing the often observed poor $\mathrm{N}_{2}$ selectivity $[10,11,22,29]$. The $\mathrm{CH}_{4} / \mathrm{NO}-\mathrm{SCR}$ reaction can be selective for $\mathrm{N}_{2}$ formation, however, the $\mathrm{N}_{2}$ selectivity of the overall NO-SCR reaction can be lower if the $\mathrm{NO}_{2}$ formed in the NO-COX reaction is not fully consumed in the coupled $\mathrm{CH}_{4} / \mathrm{NO}-\mathrm{SCR}$ reaction.

It is worth to compare the activity of the Co-oxide promoted $\mathrm{In}, \mathrm{H}$ - zeolites, studied earlier [5,18], and that of the promoted Co,H-zeolites. An important mechanistic difference is that the formal oxidation state of $\mathrm{Co}^{2+}$ zeolite cations does not change in the catalytic cycle, whereas that of the indium alternates between the $\mathrm{In}^{3+}$ and $\mathrm{In}^{+}$states. It can be also concluded that the $\mathrm{CH}_{4} / \mathrm{NO}-\mathrm{SCR}$ activity of the $[\mathrm{InO}]^{+}$active sites is significantly higher than that of $\mathrm{Co}^{2+}$ sites. A possible reason for this difference might be the more facile formation of $\mathrm{NO}_{3}{ }^{-}$ $/ \mathrm{NO}^{+}$ion pairs on $[\mathrm{InO}]^{+}$sites than on the $\mathrm{Co}^{2+}$ sites. It is more probable that the strength of water adsorption makes the difference. Water desorption is a step of site regeneration that can be is easier from the of In,H-zeolites than from the Co,H-zeolites. 


\section{Conclusions}

Present study confirmed that the selective catalytic reduction of NO by methane over $\mathrm{Co}, \mathrm{H}$-zeolites proceeds via bifunctional mechanism. The oxidation of $\mathrm{NO}$ to $\mathrm{NO}_{2}(\mathrm{NO}-\mathrm{COX})$ proceeds over Brønsted acid sites and, if present, over Co-oxide species at a significantly higher rate. The NO-COX reaction provides $\mathrm{NO}_{2}$ intermediate for the $\mathrm{N}_{2}$-forming $\mathrm{CH}_{4} / \mathrm{NO}$ $\mathrm{SCR}$ reaction catalyzed by $\mathrm{Co}^{2+} /[\mathrm{Co}-\mathrm{OH}]^{+}$ions. The $\mathrm{NO}_{2}$ intermediate disproportionates on the latter ions giving charged $\mathrm{NO}_{3}{ }^{-} / \mathrm{NO}^{+}$species. The $\mathrm{NO}_{3}{ }^{-}$reacts with methane, whereas the $\mathrm{NO}^{+}$reacts with the product of the former reaction leading to $\mathrm{N}_{2}$ formation. The suggested mechanism accounts for the maintained charge balance during the process of generating transition states relaxing by the interconnection of $\mathrm{N}^{3+}$ and $\mathrm{N}^{3-}$ to $\mathrm{N}_{2}$.

Over Co,H-zeolites high activity and $\mathrm{N}_{2}$ selectivity is obtained over about $700 \mathrm{~K}$, where the rate of the $\mathrm{CH}_{4} / \mathrm{NO}-\mathrm{SCR}$ reaction is sufficiently high to fully consume $\mathrm{NO}_{2}$ reaction intermediate. At lower temperatures the $\mathrm{N}_{2}$-forming reaction might be limited by the rate of water desorption, which has to make the active sites again available for the reactants.

The undesired methane combustion, proceeding over Co-oxide sites, decreases the NO-SCR activity and selectivity. Therefore, the amount and nature of Co-oxide and the reaction conditions has to be optimized also with regards to methane combustion in order to get the best NO-SCR activity. 


\section{Tables}

Table 1. Catalyst preparations and their compositions

\begin{tabular}{|c|c|c|c|c|}
\hline Catalyst Sample & $\begin{array}{l}\text { Preparation } \\
\text { method }\end{array}$ & $\begin{array}{l}\mathrm{Co}(\mathrm{IE}), \\
\mathrm{wt} \%^{\mathrm{a}}\end{array}$ & $\begin{array}{l}\mathrm{Co}(\mathrm{SSR}), \\
\mathrm{wt} \%^{\mathrm{b}}\end{array}$ & $\mathrm{Co} / \mathrm{Al}_{\mathrm{F}}{ }^{\mathrm{c}}$ \\
\hline $\mathrm{Co}^{\mathrm{IE}}, \mathrm{H}-\mathrm{ZSM}-5$ & $\mathrm{IE}^{\mathrm{d}}$ & 0.34 & - & 0.125 \\
\hline $\mathrm{Co}^{\mathrm{SSR}}, \mathrm{H}-\mathrm{ZSM}-5$ & $\mathrm{SSR}^{\mathrm{e}}$ & - & 0.34 & 0.125 \\
\hline $\mathrm{Co}^{\mathrm{SSR}}, \mathrm{Co}^{\mathrm{IE}}, \mathrm{H}-\mathrm{ZSM}-5$ & IE, SSR & 0.34 & 0.34 & 0.250 \\
\hline $\mathrm{Co}^{\mathrm{IE}}, \mathrm{H}-\mathrm{M}$ & IE & 1.93 & - & 0.175 \\
\hline $\mathrm{Co}^{\mathrm{SSR}}, \mathrm{H}-\mathrm{M}$ & SSR & - & 0.68 & 0.063 \\
\hline $\mathrm{Co}^{\mathrm{SSR}}, \mathrm{Co}^{\mathrm{IE}}, \mathrm{H}-\mathrm{M}(1)$ & IE, SSR & 1.93 & 0.68 & 0.238 \\
\hline $\mathrm{Co}^{\mathrm{SSR}}, \mathrm{Co}^{\mathrm{IE}}, \mathrm{H}-\mathrm{M}(2)$ & IE, SSR & 1.93 & 1.36 & 0.301 \\
\hline
\end{tabular}

${ }^{a}$ Amount of Co introduced by IE. ${ }^{b}$ Amount of Co introduced by SSR.

${ }^{\mathrm{c}}$ Co to framework $\mathrm{Al}$ atomic ratio. ${ }^{\mathrm{d}}$ Liquid phase Ion Exchange.

${ }^{\mathrm{e}}$ Solid State Reaction.

Table 2. Results of $\mathrm{H}_{2}$-TPR experiments.

\begin{tabular}{lll}
\hline \multirow{2}{*}{ Catalyst Sample } & \multicolumn{2}{l}{ Hydrogen consumption } \\
\cline { 2 - 3 } & $\mathrm{H} / \mathrm{Co}^{\mathrm{a}}$ & $\mathrm{H} / \mathrm{Co}(\mathrm{SSR})^{\mathrm{b}}$ \\
\hline $\mathrm{Co}^{\mathrm{IE}}, \mathrm{H}-\mathrm{ZSM}-5$ & 0.08 & - \\
$\mathrm{Co}^{\mathrm{SSR}}, \mathrm{H}-\mathrm{ZSM}-5$ & 2.34 & 2.34 \\
$\mathrm{Co}^{\mathrm{SSR}}, \mathrm{Co}^{\mathrm{IE}}, \mathrm{H}-\mathrm{ZSM}-5$ & 1.24 & 2.48 \\
$\mathrm{Co}^{\mathrm{IE}}, \mathrm{H}-\mathrm{M}$ & 0.32 & - \\
$\mathrm{Co}^{\mathrm{SSR}}{ }^{,} \mathrm{H}-\mathrm{M}$ & 2.63 & 2.63 \\
$\mathrm{Co}^{\mathrm{SSR}}, \mathrm{Co}{ }^{\mathrm{IE}}, \mathrm{H}-\mathrm{M}(1)$ & 0.77 & 2.96 \\
$\mathrm{Co}^{\mathrm{SSR}}, \mathrm{Co}{ }^{\mathrm{IE}}, \mathrm{H}-\mathrm{M}(2)$ & 1.23 & 2.95 \\
\hline${ }^{\mathrm{a}} \mathrm{H} / \mathrm{Co}$ atomic ratio calculated for the total Co content. \\
${ }^{\mathrm{b}} \mathrm{H} / \mathrm{Co}$ atomic ratio calculated for the amount of Co \\
introduced by SSR.
\end{tabular}




\section{References}

[1] Y. Li, J.N. Armor, Appl. Catal. B 1 (1992) L31-L40.

[2] Y. Li, P. Battavio, J.N. Armor, J. Catal. 142 (1993) 561-571.

[3] Y. Traa, B. Burger, J. Weitkamp, Micropor. Mesopor. Mater. 30 (1999) 3-41.

[4] H.-Y. Chen, Q. Sun, B. Wen, Y.-H. Yeom, E. Weitz, W.M.H. Sachtler, Catal. Today 96 (2004) 1-10.

[5] F. Lónyi, H.E. Solt, J. Valyon, A. Boix, L.B. Gutierrez, Appl. Catal. B 117-118 (2012) 212-223.

[6] Y. Li, T.L. Slager, J.N. Armor, J. Catal. 150 (1994) 388-399.

[7] L.J. Lobree, A.W. Aylor, J.A. Reimer, A.T. Bell, J. Catal. 169 (1997) 188-193.

[8] T. Sun, M.D. Fokema, J.Y. Ying, Catalysis Today, 33 (1997) 251-261.

[9] N.W. Cant, I.O.Y. Liu, Catal. Today 63 (2000) 133-146.

[10] C. Resini, T. Montanari, L. Nappi, G. Bagnaco, M. Turco, G. Busca, F. Bregani, N. Notaro, G. Rocchini, J. Catal. 214 (2003) 179-190.

[11] G. Bagnasco, M. Turco, C. Resini, T. Montanari, M. Bevilacqua, G. Busca, J. Catal. 225 (2004) 536-540.

[12] G. Busca, M.A. Larrubia, L. Arrighi, G. Ramis, Catal. Today 107-108 (2005) 139-148.

[13] X. Wang, H. Chen, W.M.H. Sachtler, J. Catal. 197 (2001) 281-291.

[14] J.A. Rabo, P.H. Kasai: Caging and electrolytic phenomena in zeolites. Prog. Solid State Chem., 9 (1975), pp. 1-19.

[15] M. Li, Y. Yeom, E. Weitz, W.M.H. Sachtler, J. Catal. 235 (2005) 201-208.

[16] C. Henriques, O. Marie, F. Thibault-Starzyk, J.-C. Lavalley, Micropor. Mesopor. Mater. 50 (2001) 167-171.

[17] F. Lónyi, J. Valyon, L. Gutierrez, M.A. Ulla, E.A. Lombardo, Appl. Catal. B 73 (2007) 1-10.

[18] F. Lónyi, H.E. Solt, J. Valyon, H. Decolatti, L.B. Gutierrez, E. Miró, Appl. Catal. B 100 (2010) 133-142.

[19] I. Halasz, A. Brenner, K.Y. Simon Ng, Ying Hou, J. Catal., 161 (1996) 359-372.

[20] D.B. Lukyanov, G. Sill, J.L. d'Itri, W.K. Hall, J. Catal. 153 (1995) 265-274.

[21] D.B. Lukyanov, E.A. Lombardo, G.A. Sill, J.L. d'Itri, W.K. Hall, J. Catal. 163 (1996) 447-456.

[22] D. Kaucky, A. Vondrova, J. Dedecek, B. Wichterlova, J. Catal. 194 (2000) 318-329.

[23] A. Kubacka, J. Janas, E. Wloch, B. Sulikowski, Catal. Today 101 (2005) 139-145.

[24] A. Kubacka, J. Janas, B. Sulikowski, Appl. Catal. B 69 (2006) 43-48.

[25] X. Wang, H. Chen, W.M.H. Sachtler, Appl. Catal. B 29 (2001) 47-60.

[26] X. Wang, H.-Y. Chen, W.M.H. Sachtler, Appl. Catal. B 26 (2000) L227-L239.

[27] L.B. Gutierrez, E.E. Miró, M.A. Ulla, Appl. Catal. A 321 (2007) 7-16.

[28] M. Mhamdi, S. Khaddar-Zine, A. Ghorbel, Appl. Catal. A 357 (2009) 42-50.

[29] C. Chupin, A.C. van Veen, M. Konduru, J. Deprés, C. Mirodatos, J. Catal. 241 (2006) 103-114.

[30] T. Montanari, O. Marie, M. Daturi, G. Busca, Appl. Catal. B 71 (2007) 216-222.

[31] J. Zhang, W. Fan, Y. Liu, R. Li, Appl. Catal. B 76 (2007) 174-184.

[32] R. Burch, J.P. Breen, F.C. Meunier, Appl. Catal. B 39 (2002) 283-303.

[33] M.C. Campa, S. De Rossi, G. Ferraris, V. Indovina, Appl. Catal. B 8 (1996) 315-331.

[34] L. Gutierrez, A. Boix, J. O. Petunchi, J. Catal. 179 (1998) 179-191.

[35] M. Mohai, Surf. Interface Anal. 36 (2004) 828-832. 
[36] L. Gutierrez, E.A. Lombardo, Appl. Catal. A 360 (2009) 107-119.

[37] J.A.Z. Pieterse, R.W. van den Brink, S. Booneveld, F.A. de Bruijn, Appl. Catal. B 46 (2003) 239-250.

[38] M.M. Yung, E.M. Holmgreen, U.S. Ozkan, J. Catal. 247 (2007) 356-367.

[39] K. Hadjiivanov, J. Saussey, J.L. Freysz, J.C. Lavalley, Catal. Lett. 52 (1998) 103-108.

[40] A. Zecchina, F. Geobaldo, G. Spoto, S. Bordiga, G. Ricchiardi, R. Buzzoni, G. Petrini, J. Phys. Chem. 100 (1996) 16584-16599.

[41] M.C. Campa, V. Indovina, J. Porous Mater. 14 (2007) 251-261.

[42] S.M. Auerbach, K.A. Corrado, P.K. Dutta (Eds.), Handbook of Zeolite Science and Technology, Marcel Dekker Inc., New York, Basel, 2003, p. 440.

[43] K.I. Hadjiivanov, Catal Rev.: Sci. Eng. 42 (1-2) (2000) 71-144.

[44] K. Hadjiivanov, B. Tsyntsarski, T. Nikolova, Phys. Chem. Chem. Phys. 1 (1999) 4521-4528.

[45] E. Ivanova, K. Hadjiivanov, D. Klissurski, M. Bevilacqua, T. Armaroli, G. Busca, Micropor. Mesopor. Mater. 46 (2001) 299-309.

[46] T. Weingand, S. Kuba, K. Hadjiivanov, H. Knozinger, J. Catal. 209 (2002) 539-546.

[47] J. Dedecek, B. Wichterlova, J. Phys. Chem. B 103 (1999) 1462-1476.

[48] K. Hadjiivanov, E. Ivanova, M. Daturi, J. Saussey, J.-C. Lavalley, Chem. Phys. Lett. 370 (2003) 712-718.

[49] K. Gora-Marek, B. Gil, M. Sliwa, J. Datka, Appl. Catal. A 330 (2007) 33-42.

[50] K. Gora-Marek, Top. Catal. 52 (2009) 1023-1029.

[51] V. Indovina, M.C. Campa, D. Pietrogiacomi, J. Phys. Chem. C 112 (2008) 5093-5101.

[52] P. Pietrzyk, C. Dujardin, K. Góra-Marek, P. Granger, Z. Sojka, Phys. Chem. Chem. Phys. 14 (2012) 22032215 .

[53] M.C. Campa, I. Luisetto, D. Pietrogiacomi, V. Indovina, Appl. Catal. B 46 (2003) 511-522.

[54] J. Dedecek, D. Kaucky, B. Wichterlova, Top. Catal. 18 (2002) 283-290.

[55] J. Dedecek, D. Kaucky, B. Wichterlova, Microporous Mesoporous Mater. 35-36 (2000) 483-494.

[56] B. Mirkelamoglu, U.S. Ozkan, Appl. Catal. B 96 (2010) 421-433.

[57] A.D. Cowan, R. Dümpelmann, N.W. Cant, J. Catal. 151 (1995) 356-363.

[58] E.A. Lombardo, G.A. Sill, J.L. d'Itri, W.K. Hall, J. Catal. 173 (1998) 440-449. 


\section{Figures}
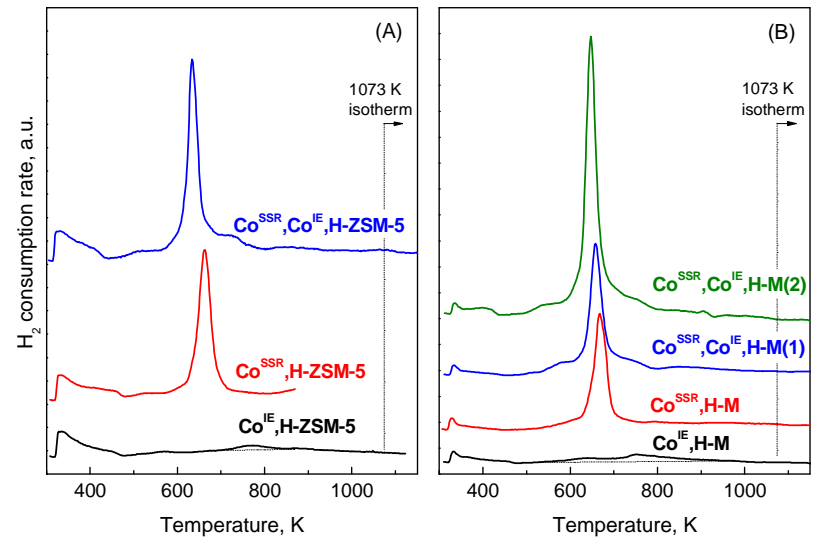

Fig. 1. $\mathrm{H}_{2}$-TPR characterization of cobalt zeolite (A) ZSM-5 and (B) mordenite. The cobalt was introduced in the zeolite samples by conventional ion exchange (IE) and/or solid state reaction with cobalt salt. Samples were pretreated in situ in $\mathrm{O}_{2}$ flow at $773 \mathrm{~K}$ for $1 \mathrm{~h}$ then purged with $\mathrm{N}_{2}$ at $773 \mathrm{~K}$ and cooled to room temperature. Reduction was initiated by switching the $\mathrm{N}_{2}$ flow to a $10 \% \mathrm{H}_{2} / \mathrm{N}_{2}$ flow and ramping up the temperature to $1073 \mathrm{~K}$ at a rate of $10 \mathrm{~K} \cdot \mathrm{min}^{-1}$.

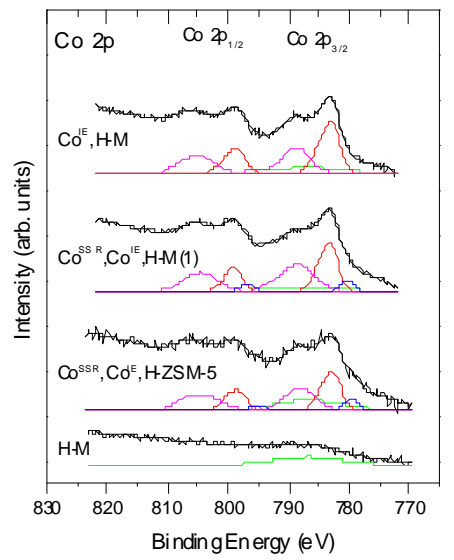

Fig. 2. XPS spectra of the Co-zeolite catalyst preparations in the Co $2 p$ region. Catalyst samples were pretreated in situ in vacuum at $673 \mathrm{~K}$ for $1 \mathrm{~h}$, then cooled to room temperature. The spectrum of H-M is shown for comparison. Its broad feature arises from the plasmon loss band of the $\mathrm{O} 1 \mathrm{~s}$ peak excited by the (unused) Mg X-ray anode due to crosstalk. 

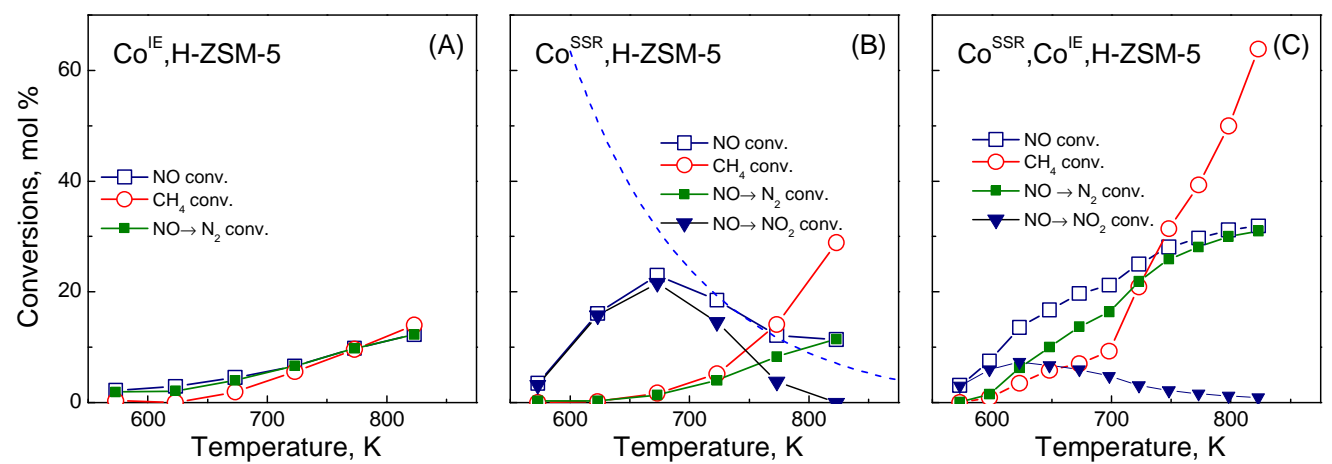

Fig. 3. The conversion of $\mathrm{NO}$ and $\mathrm{CH}_{4}$ in the NO-SCR reaction over Co,H-ZSM-5 catalysts. The reactant flow was $4000 \mathrm{ppm} \mathrm{NO} / 4000 \mathrm{ppm} \mathrm{CH}_{4} / 2 \% \mathrm{O}_{2} / \mathrm{He}$ gas mixture, the GHSV was $30000 \mathrm{~h}^{-1}$. Before reaction catalysts were treated in situ in $10 \% \mathrm{O}_{2} / \mathrm{He}$ flow at $823 \mathrm{~K}$ for $1 \mathrm{~h}$ then purged with $\mathrm{He}$ at the same temperature. The dashed curve in part (B) shows the equilibrium concentration of $\mathrm{NO}_{2}$.
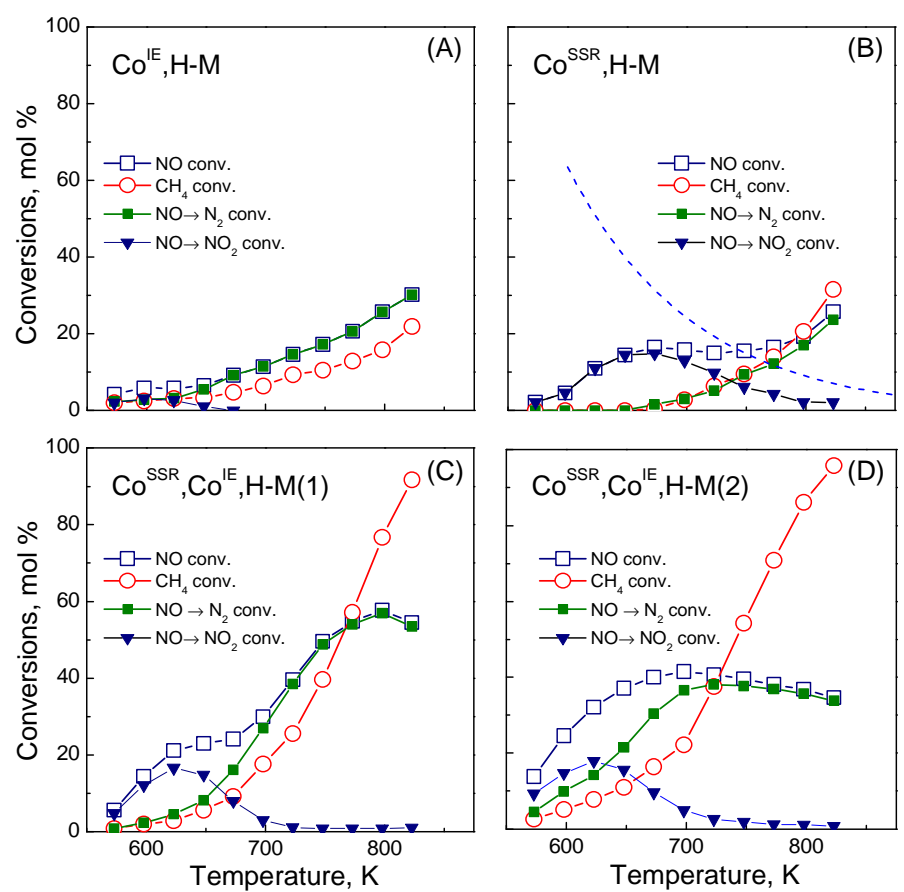

Fig. 4. The conversion of $\mathrm{NO}$ and $\mathrm{CH}_{4}$ in the NO-SCR reaction over $\mathrm{Co}, \mathrm{H}-\mathrm{M}$ catalysts. For experimental details see legend of Fig. 3. 

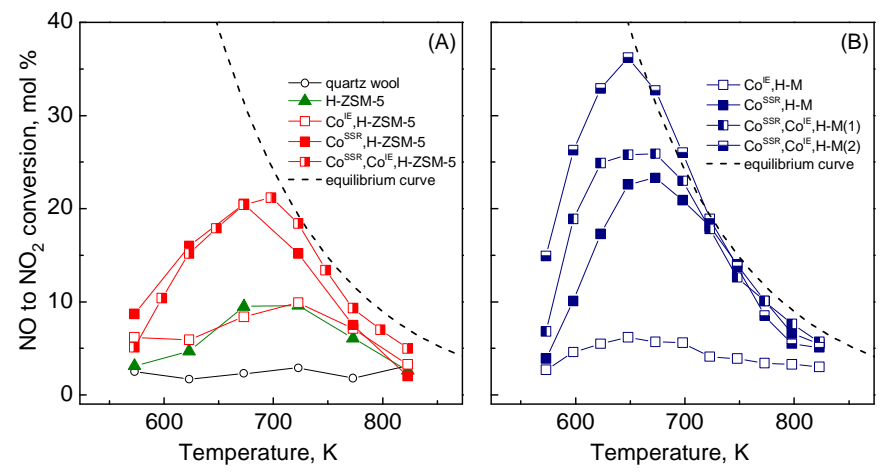

Fig. 5. The conversion of $\mathrm{NO}$ to $\mathrm{NO}_{2}$ by $\mathrm{O}_{2}$ over (A) Co,H-ZSM-5 and (B) Co,H-M catalysts. The reactant flow was $4000 \mathrm{ppm} \mathrm{NO} / 2 \% \mathrm{O}_{2} / \mathrm{He}$ gas mixture, the GHSV was $30000 \mathrm{~h}^{-1}$. The dashed curve shows the equilibrium concentration of $\mathrm{NO}_{2}$.
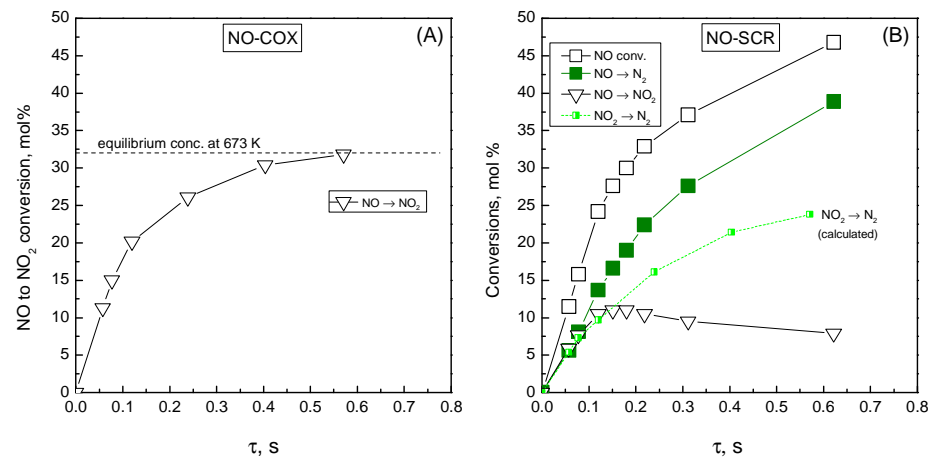

Fig. 6. The conversion of $\mathrm{NO}$ to (A) $\mathrm{NO}_{2}$ in the catalytic oxidation by $\mathrm{O}_{2}(\mathrm{NO}-\mathrm{COX})$ and (B) to $\mathrm{N}_{2}$ and $\mathrm{NO}_{2}$ in the NO-SCR reaction in the function of space time at $673 \mathrm{~K}$ over $\mathrm{Co}^{\mathrm{SSR}}, \mathrm{Co}^{\mathrm{IE}}, \mathrm{H}-\mathrm{M}(1)$ catalyst. The reactant was either $4000 \mathrm{ppm} \mathrm{NO} / 2 \% \mathrm{O}_{2} / \mathrm{He}$ or $4000 \mathrm{ppm}$ $\mathrm{NO} / 4000 \mathrm{ppm} \mathrm{CH}_{4} / 2 \% \mathrm{O}_{2} / \mathrm{He}$ gas mixture. The GHSV was changed between 6000 and $60000 \mathrm{~h}^{-1}$ in order to get the desired space time. 


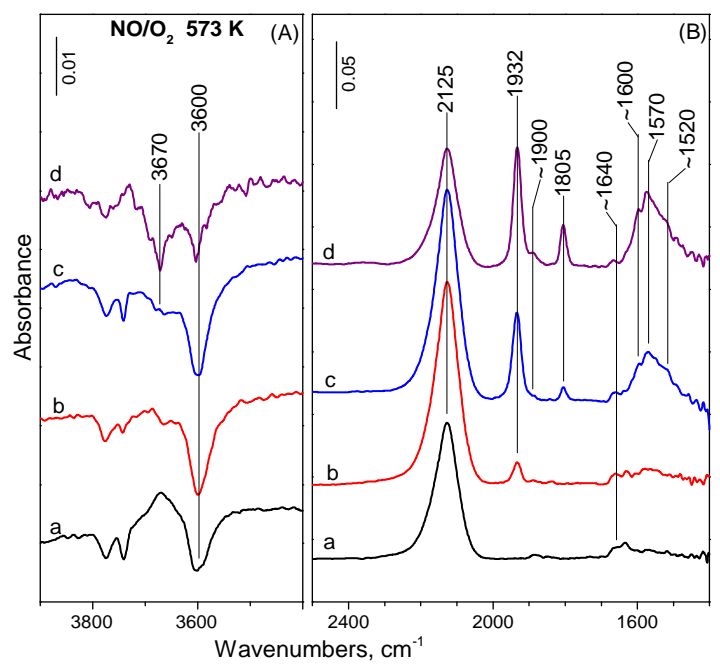

Fig. 7. Difference DRIFT spectra of the catalyst (a) $\mathrm{H}-\mathrm{ZSM}-5$, (b) $\mathrm{Co}^{\mathrm{SSR}}, \mathrm{H}-\mathrm{ZSM}-5$, (c) $\mathrm{Co}^{\mathrm{IE}}, \mathrm{H}-\mathrm{ZSM}-5$ and (d) $\mathrm{Co}^{\mathrm{SSR}}, \mathrm{Co}^{\mathrm{IE}}, \mathrm{H}-\mathrm{ZSM}-5$ in contact with a continuous flow of $4000 \mathrm{ppm}$ $\mathrm{NO} / 2 \% \mathrm{O}_{2} / \mathrm{He}$ gas mixture at GHSV $30000 \mathrm{~h}^{-1}$ and $573 \mathrm{~K}$. (A) The $v_{\mathrm{OH}}$ region and (B) the spectra of the adsorbed $\mathrm{NO}_{\mathrm{x}}$ species.

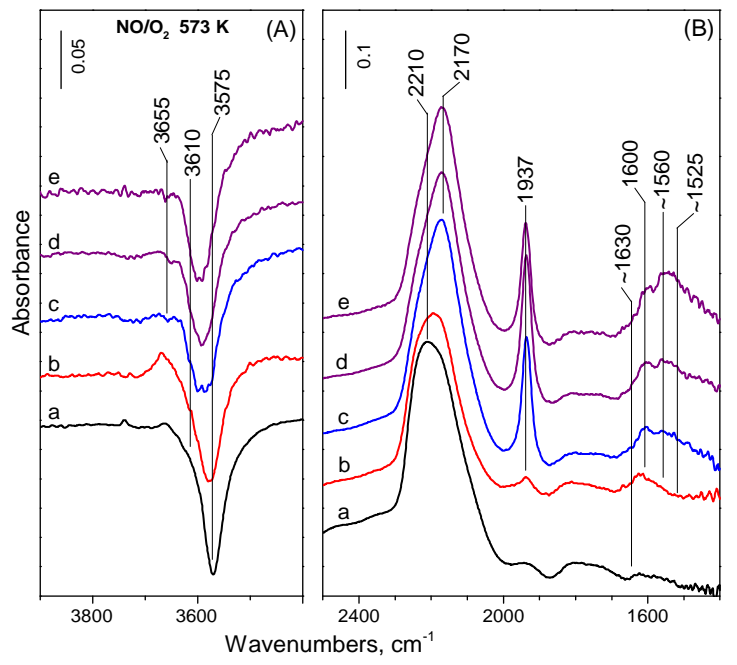

Fig. 8. Difference DRIFT spectra of the catalyst (a) H-M, (b) $\mathrm{Co}^{\mathrm{SSR}}, \mathrm{H}-\mathrm{M}$, (c) $\mathrm{Co}^{\mathrm{IE}}, \mathrm{H}-\mathrm{M}$, (d) $\mathrm{Co}^{\mathrm{SSR}}, \mathrm{Co}^{\mathrm{IE}}, \mathrm{H}-\mathrm{M}(1)$ and (e) $\mathrm{Co}^{\mathrm{SSR}}, \mathrm{Co}^{\mathrm{IE}}, \mathrm{H}-\mathrm{M}(2)$ in contact with a continuous flow of 4000 ppm NO/2\% $\mathrm{O}_{2} / \mathrm{He}$ gas mixture at GHSV $30000 \mathrm{~h}^{-1}$ and $573 \mathrm{~K}$. (A) The $v_{\mathrm{OH}}$ region and (B) the spectra of the adsorbed $\mathrm{NO}_{\mathrm{x}}$ species. 


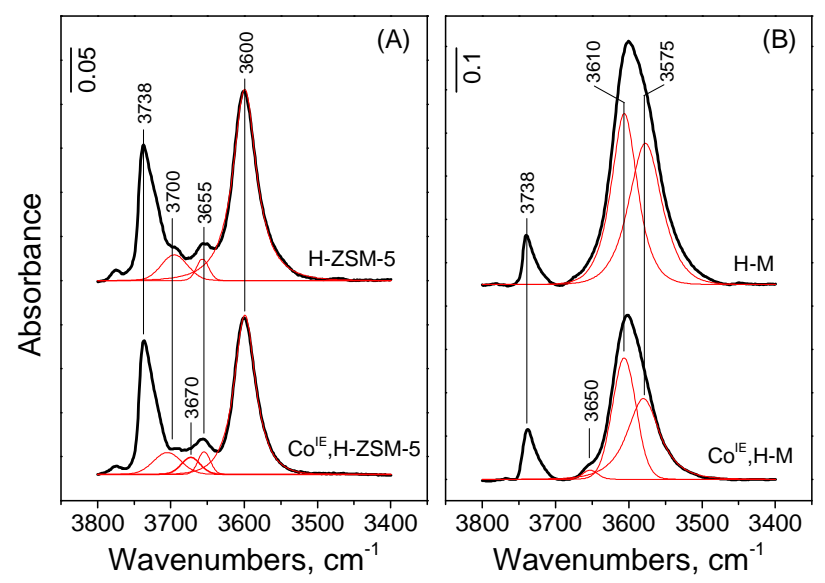

Fig. 9. DRIFT spectra of the $v_{\mathrm{OH}}$ region for (A) $\mathrm{H}-\mathrm{ZSM}-5$ and $\mathrm{Co}^{\mathrm{IE}}, \mathrm{H}-\mathrm{ZSM}-5$ sample and (B) $\mathrm{H}-\mathrm{M}$ and $\mathrm{Co}^{\mathrm{IE}}, \mathrm{H}-\mathrm{M}$ sample (thick lines). The spectra were recorded in He flow at $573 \mathrm{~K}$. Thin lines indicate the component bands obtained by a curve fitting computer program.

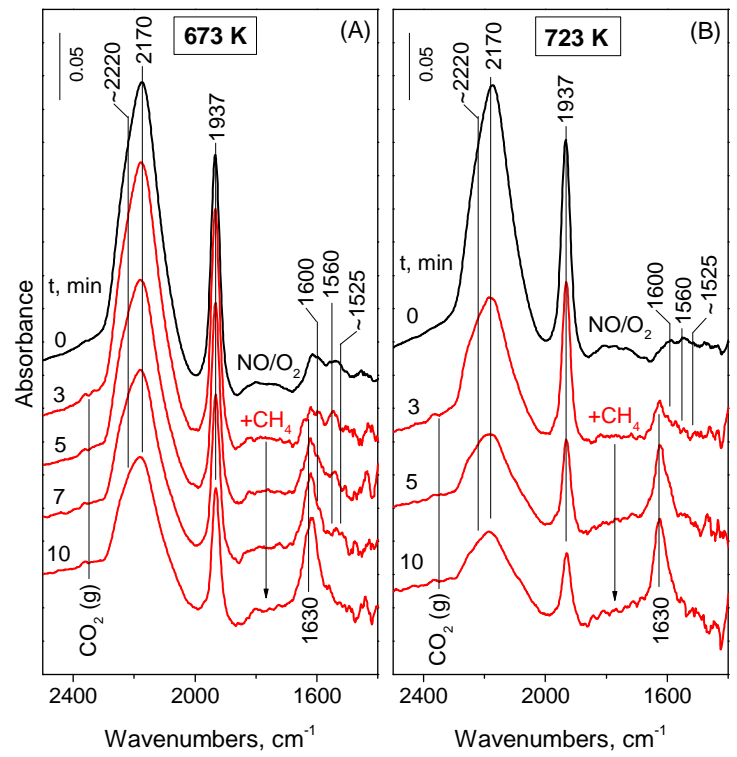

Fig. 10. Operando DRIFT spectroscopic examination of the transient response of the $\mathrm{Co}^{\mathrm{SSR}}, \mathrm{Co}^{\mathrm{IE}}, \mathrm{H}-\mathrm{M}(1)$ catalyst on the change of the reactant composition. Catalyst was contacted with a flow of $4000 \mathrm{ppm} \mathrm{NO} / 2 \% \mathrm{O}_{2} / \mathrm{He}$ at GHSV $30000 \mathrm{~h}^{-1}$ at (A) $673 \mathrm{~K}$ and (B) $723 \mathrm{~K}$. The first spectrum was recorded after the steady state was established (uppermost spectrum), then the flow was abruptly changed to a similar flow of $4000 \mathrm{ppm} \mathrm{NO} / 4000 \mathrm{ppm} \mathrm{CH}_{4} / 2 \% \mathrm{O}_{2} / \mathrm{He}$ (indicated as $+\mathrm{CH}_{4}$ ). Spectra were recorded after the given time on stream. The spectrum of the catalyst in $\mathrm{He}$ at the corresponding reaction temperature $(673 \mathrm{~K}$ or $723 \mathrm{~K})$ was subtracted from each spectrum and the difference spectra are shown. 


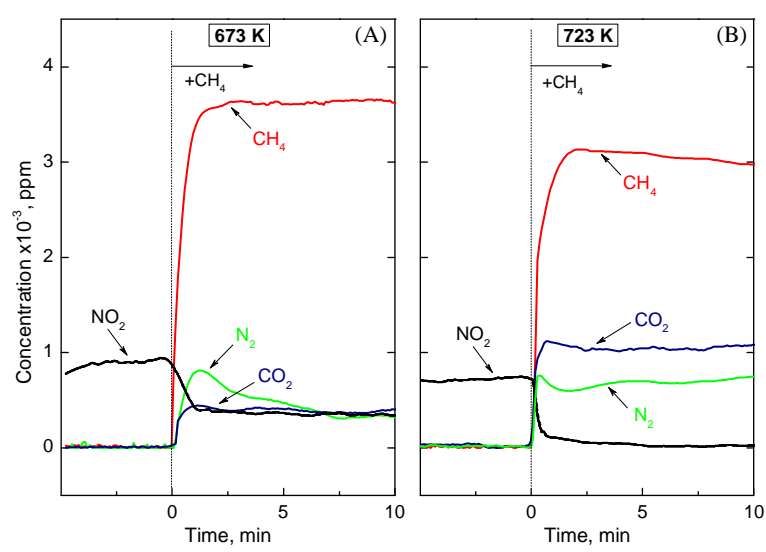

Fig. 11. Concentrations of the $\mathrm{CH}_{4}$ and reaction products $\mathrm{N}_{2}, \mathrm{NO}_{2}$ and $\mathrm{CO}_{2}$ in the effluent from the experiments of Fig. 10 at reaction temperature of (A) $673 \mathrm{~K}$ and (B) $723 \mathrm{~K}$ as a function of time from the moment of switching the $\mathrm{NO} / \mathrm{O}_{2} / \mathrm{He}$ flow to a flow of $\mathrm{CH}_{4} / \mathrm{NO} / \mathrm{O}_{2} / \mathrm{He}$.

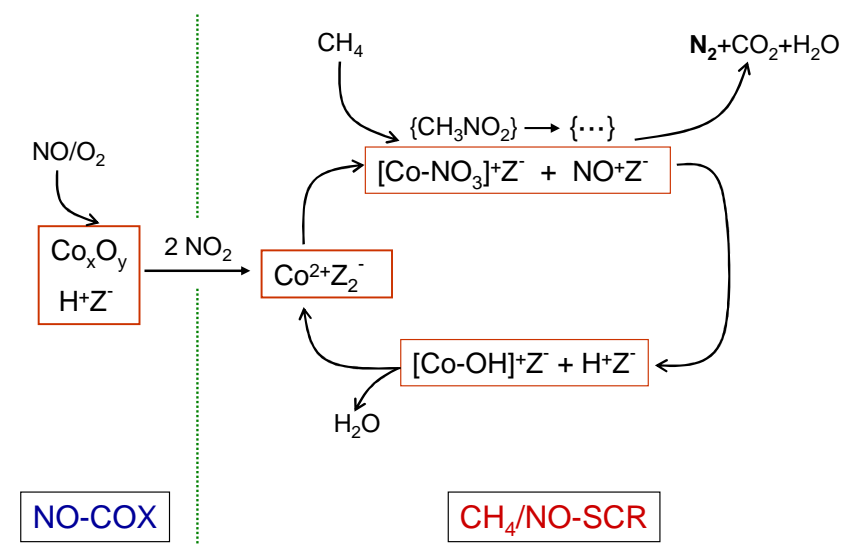

Scheme 1. The mechanism of NO-SCR reaction by methane over Co-oxide promoted Cozeolites. 